\title{
3 „Fiktion“ und „Wirklichkeit“: Beziehungsmuster in Philosophie und Literaturtheorie
}

\author{
Die im Rahmen der vorliegenden Abhandlung als Korpus behandelten Literatur- \\ theorien sind konkrete Manifestationen und literaturbezogene Anwendungen \\ philosophischer Vorstellungen von Begriffspaaren, die auf verschiedenen Ebe- \\ nen anzusiedeln sind: „Gestaltloses - Gestalthaftes“, 80 „Geist - Materie“, 81 „Un- \\ wandelbares - Wandelbares“ ${ }^{\text {(82 }}$ sowie „Fiktion - Wirklichkeit“"83. Alle diese und \\ weitere verwandte Begriffspaare berühren das Kernproblem der philosophischen \\ Disziplin der Metaphysik, und die meisten in Literaturtheorien vorgefundenen \\ Verweise auf metaphysische Spekulationen befassen sich mit Fragen konstituti- \\ ver Seinsbestimmungen (Ontologie) im Allgemeinen sowie im Besonderen mit
}

80 Wörtliche Bezeichnungen für das Gestaltlose sind wuxing 無形 („,keine Form haben“) und wudi 無体 (,keinen Körper haben“), für das Gestalthafte deren Antonyme youxing 有形 („eine Form haben“) und youdi 有体 (,einen Körper haben“). Die noch heute für Metaphysisches und Physisches verwendeten Begriffe xing er shang 形而上 („über der Form sein“) und xing er xia 形 而下 (,unter der Form sein“) spielen auf das Folgende im Kapitel 12.4 (Xici shangzhuan 繫辞上 伝) enthaltene Philosophem des Yijing (The I Ching) an: 是故、形而上者謂之道、形而下者謂之 器。 (Zixia Yizhuan 子夏易傳 7: 22a, SKQS-Edition). „Hence that which is antecedent to the material form exists, we say, as an ideal method, and that which is subsequent to the material form exists, we say, as a definite thing“ (LEGGE 1882: 377). Zu einer höheren Abstraktionsstufe gehört die Bezeichnung $x u$ 虚 (jap. kyo, „Leere“), welche nicht die Gestaltlosigkeit (die Abwesenheit eines befüllbaren Körpers) selbst, sondern ihr Ergebnis bezeichnet.

81 Gängige chinesische Bezeichnungen für „Geist“ sind shen 神 (jap. shin) und gueishen 鬼神 (jap. kishin, kijin) (KRACHT 1986: 2-3). „Materie“ wird häufig mit wu 物 (jap. butsu, „Ding“) und qi 気 (jap. ki, „Äther“) bezeichnet. Klaus Kracht übersetzt qi mit „Materie“ (КRACHT 1986: 41), WingTsit Chan wählt „material force“ (CHAN 1970 [1963]: 784). Mit „Äther“ folge ich der von Hane Mikiso getroffenen Wahl, die ihrerseits (in MARUYAMA-HANE 1974: 22) Derk Bodde (in FunG-BodDE 1983-2: 20) folgt. Dabei ist mir bewusst, dass die im Originalbegriff $q i$ enthaltene Wirkungsqualität in „Äther“ nicht zum Ausdruck kommt und auch das Problem des Aggregatzustands damit nicht gelöst ist.Zu einer höheren Konkretionsstufe gehört die Bezeichnung shi 実 (jap. jitsu, „Frucht“), welche nicht die Materie selbst, sondern das Ergebnis ihrer Funktion als Wirkstoff bezeichnet.

82 Die wörtliche Bezeichnung für das Unwandelbare ist buyi 不易 (jap. fueki), für das Wandelbare wird häufig die Metapher liuxing 流行 (jap. ryūkō, „fließen und davongehen“) verwendet. 83 Häufig verwendete wörtliche und überwiegend wertneutrale Bezeichnungen für Fiktion sind zuowu 作物 (jap. sakubutsu; nur in der Lesung sakumotsu konkret für „Ernte“) und zuowei 作為 (jap. sakui), für Wirklichkeit shiwu 実物 (jap. jitsubutsu, „Frucht als Gegenstand“) und shizai 実在 (jap. jitsuzai, „tatsächlich existent“). Negativ besetzt sind häufig die Bezeichnungen $x u$ 虚 (jap. kyo, „Leere“) und das japanische tsukurimono 作物 („Gemachtes“) für die Fiktion, positiv besetzt dagegen ziran 自然 (jap. shizen oder jinen, „so Seiendes“, „Natur“).

Ә Open Access. (C) 2022 Guido Woldering, publiziert von De Gruyter. (c)) BY-NC-ND Dieses Werk ist lizenziert unter einer Creative Commons Namensnennung - Nicht-kommerziell - Keine Bearbeitung 4.0 International Lizenz. https://doi.org/10.1515/9783110763942-004 
Fragen der Konstituierung von Wirklichkeit durch Vereinigung von Materie und Geist, Subjekt und Objekt sowie Denken und Sein (Identitätsphilosophie). Was ontologische und identitätsphilosophische Fragen mit der Dichotomie „Fiktion Wirklichkeit“ verbindet, erhellt sich aus der Etymologie des Wortes „Fiktion“ (< lat. fingere, „herstellen“): Den besonderen Zusammenhang zwischen „Leere“ und „Fülle“, „Blüte“ (ka 花) und „Frucht“ (jitsu 実), „Gestaltlosem“ (mukei 無形) und „Gestalthaftem“ (yūkei 有形), „Unwandelbarem“ (fueki 不易) und „Wandelbarem“ (ryūkō 流行) sowie „Geist“ und „Materie“, „Denken“ und „Sein“ innerhalb eines philosophischen oder literarischen Werkes stellen deren Verfasser erst durch ihre Sprachhandlung her. Die negative Assoziation, welche dem Wort „Fiktion“ im Alltag anhaften mag, muss suspendiert werden, um das Ergebnis der Herstellung wertungsfrei betrachten zu können. ${ }^{84}$

Treten wir aber zunächst einen Schritt zurück und betrachten - in der gebotenen Kürze - das für Philosophen und Literaten verfügbare „Material“! Eine der am frühesten in China nachweisbaren und zugleich der am weitesten verbreiteten begrifflichen Dichotomien ist xushi 虚実 („Leere und Fülle“, jap. kyojitsu). Die Ubiquität mag mit den nachstehend zusammengetragenen, sehr weit gefassten Bedeutungsspektren der Wortbestandteile und der sie repräsentierenden Zeichen zusammenhängen.

Tabelle 6: Wort- und Zeichenetymologie für xushi 虚実.

\begin{tabular}{|c|c|c|}
\hline Wort und Zeichen & Wortetymologie & Zeichenetymologie \\
\hline$x u$ 虚 & $\begin{array}{l}\text { Ruinenhügel, } \\
\text { Bescheidenheit }^{85}\end{array}$ & $\begin{array}{l}\text { aus der Siegelschrift stammendes } \\
\text { Derivat von 盧, versenkter Hohlraum; } \\
\text { Loch; Leere }^{86}\end{array}$ \\
\hline shi 実 & $\begin{array}{l}\text { Frucht, Festigkeit, Fülle, } \\
\text { Reichtum }^{87}\end{array}$ & Frucht, Fülle ${ }^{88}$ \\
\hline
\end{tabular}

Aus der Einengung der ursprünglich sehr weiten Bedeutungsfelder sowohl der Wörter als auch der Zeichen ergeben sich für beide Bestandteile jene vom Sinologen Morohashi Tetsuji 諸橋轍次 (1883-1982) im Dai kanwa jiten 大漢和辞典 (DKJ) zusammengetragenen, völlig verschiedenen Interpretationen mit teilweise starken

84 Auf diesen Aspekt verweist auch BucK-AlBulEt 2008.

85 SCHUESSLER 1987: 694; 696.

86 DKJ 9-32709.

87 SCHUESSLER 1987: 543-544.

88 DKJ 3-7294. 
moralischen Implikationen. Für $x u$ 虚 finden sich die Bedeutungsfelder „Abwesenheit“ ( $\rightarrow$ Unsichtbarkeit, Seele, nicht existent, geringfügig, ungenügend, ausgetrocknet, Himmel) und „Loch“ ( $\rightarrow$ Freizeit, Gedankenlosigkeit, Inhaltslosigkeit, Unehrlichkeit), für shi 実 die Bedeutungsfelder „Anwesenheit“ ( $\rightarrow$ Samen, Fruchtbarkeit, Inhalt) und „Tatsache“ ( $\rightarrow$ Wahrhaftigkeit, Opfergabe).

Die erste nachgewiesene Verwendung der aus $x u$ und shi gebildeten Dichotomie ist die Kapitelüberschrift Xushi bian 虚実篇 ([Kapitel von Leere und Fülle]) der militärstrategischen Abhandlung Sunzi bingfa 孫子兵法 (4. Jh. v. Chr.; SunTzu: The Art of Warfare) des Sunzi (544-496 v. Chr.) ${ }^{89}$ Dort bezeichnet der Ausdruck schlicht Schwächen $(x u)$ und Stärken (shi) des Gegners ${ }^{90}$ und hat nichts mit Literatur zu tun. Auf einer völlig anderen Ebene bewegen sich die weiter unten zu behandelnden Denker und unterstreichen die schon auf der Ebene der Etymologie sichtbare enorme begriffliche Bandbreite, innerhalb derer sich japanische Literaturtheoretiker bewegen.

\subsection{Drei logisch mögliche Beziehungen zwischen den Bestandteilen einer Dichotomie in philosophischen und literaturtheoretischen Texten - das Beispiel „Leere - Fülle“}

Die für xushi (kyojitsu) konstatierte Bandbreite ist auch Begriffspaaren wie etwa „Gestaltloses - Gestalthaftes“, „Geist - Materie“, „Unwandelbares - Wandelbares“ sowie „Fiktion - Wirklichkeit“ in der Literaturtheorie Chinas und Japans feststellbar. Die großen Deckungen gründen einerseits darin, dass sie alle in Diskussionen allgemein ontologischer Fragen und Fragen der Konstitutierung von Realität durch Vereinigung von Materie und Geist, Subjekt und Objekt sowie Denken und Sein (Identitätsphilosophie) verwendet werden. Andererseits gründen die großen Deckungen aber vielfach auch in ihrer konkreten Anwendung, die häufig etymologische und semantische Unterschiede ignoriert oder nivelliert.

89 Viele der im Folgenden passierten Stationen der Begriffsgeschichte wurden von KonISHI 1946 markiert.

90 夫兵形象水。水之形、避高而趨下。兵之形、避實而擊虚。 (Sunzi子系子 6: 9b, SKQS-Edition) „The positioning (hsing) of troops can be likened to water: Just as the flow of water avoids high ground and rushes to the lowest point, so on the path to victory avoid the enemy's strong points and strike where he is weak" (SUNZI-AmES 1993: 126-127). Die wörtlichere Übersetzung liefert Lionel Giles wie folgt: „Military tactics are like unto water; for water in its natural course runs away from high places and hastens downwards. So in war, the way is to avoid what is strong [shi] and to strike at what is weak [xu]" (SunZI-GILES 2004: 58). 
Beispielsweise werden in einigen Theorien „Leere“ mit Immaterialität und „Fülle“ mit Materialität schlicht gleichgesetzt. Texte, die immaterielle und materielle Referentia miteinander verbinden, werden in der traditionellen Literaturtheorie der späten Edo-Zeit häufig positiv beurteilt, wenn der Text dem Theoretiker geeignet erscheint, das immaterielle Referens als Grundlage des materiellen darzulegen, also die beiden Bestandteile zu einer Einheit zusammenfügt. In anderen Theorien wird Gestaltlosigkeit mit der a priori gewonnenen Erkenntnis des Gegenstandes an sich inhaltlich verbunden, Gestalthaftigkeit dem a posteriori erkennbaren Gegenstand. Zusammenfügungen der genannten Arten sollen unabhängig von der enthaltenen Wertung im Folgenden „synthetisch“ genannt werden. In gedanklich weniger tiefschürfenden Theorien werden „Leere“ mit „Nutzlosigkeit“ und „Fülle“ mit „Nützlichkeit“ gleichgesetzt oder ähnliche Dichotomien gebildet. ${ }^{91}$ Aus solchen Gleichsetzungen erwachsen zumeist negative Bewertungen derjenigen Sprechakte, die zusammenfügen, was nach Meinung des Theoretikers nicht zusammengefügt werden dürfte. Zusammenfügungen dieser Art sollen unabhängig von der enthaltenen Wertung im Folgenden „analytisch“ genannt werden. Zwischen diesen beiden Polen liegt der Großteil der zu behandelnden, in Ausrichtung und Tiefgang unterschiedlichen Literaturtheorien. ${ }^{92}$

Wir müssen uns daher in Bezug auf die Teile einschlägiger begrifflicher Dichotomien zunächst der prinzipiellen Möglichkeiten ihrer Beziehung zueinander versichern. Die in einem Text generell herstellbar erscheinenden Beziehungen zwischen „Leere“ und „Fülle“ und ähnlichen Dichotomien lassen sich im Lichte der einschlägigen Äußerungen in Philosophie und Literaturtheorie in folgenden

91 Der häufiger nicht einmal argumentierte normative Anspruch hinter solchen Zuordnungen prägt in Japan noch heute den alltäglichen Sprachgebrauch. So wird der Betreiber eines Wirtschaftsunternehmens mit dem positiv konnotierten Wort jitsugyōka 実業家 („Person fruchtbringender Unternehmungen“) selbst dann bezeichnet, wenn die Früchte seiner Unternehmung Atomkatastrophen sind. Zweifellos gab und gibt es in Japan auch Zustimmung zum schon von Cao Pi 曹丕 (187-226), dem ersten Kaiser der chinesischen Wei-Dynastie, in Dianlun 典論 ([Über Normen < der Literatur >]) wie folgt formulierten Loblied auf Texte im Allgemeinen: 蓋文章経国之 大業、不朽之盛事。(Wenxuan zhu 文選注 52: 9a, SKQS-Edition). „Texte sind fürwahr großartige Unternehmungen der Staatsführung, blühender und unvergänglicher Dienst.“ Als Teil der in Japan intensiv rezipierten Anthologie Wenxuan 文選 (Selections of Refined Literature, 526-531), aus der ich hier zitiere, wurde auch das Dianlun in Japan früh bekannt. Allerdings wurden im japanischen Zusammenhang unter der für die Staatsführung fruchtbaren „Literatur“ meist die konfuzianischen Klassiker (und nicht die fiktionale Literatur) verstanden, wie nicht zuletzt MAEDA 2012, ҮокотА 2015 und OKAMURA 2017 darlegen.

92 In den Literaturtheorien werden die oben genannten Begriffe nicht nur anhand dieser Beispiele, sondern auch durch zahlreiche andere, analog gebildete Metaphern vermittelt. 
drei Modellen verdichten. Dabei steht das Rechteck für den Text, die Kreise stehen für die im Text direkt oder indirekt erfassten Gegenstände.

Gegenüber dem wissenschaftlichen Text stellt die Theorie den Anspruch, er möge „Fülle“ und „Leere“ (oder andere Bestandteile einer Dichotomie) explizit nennen, erläutern und komplett in einen konsistenten Zusammenhang integrieren. Ein solcher Text wird im Falle der Philosophie und der Literaturtheorie im Japan der Vormoderne und deren chinesischen Quellen nicht als Fiktion („Gemachtes“, tsukuri) verstanden, sondern als Aufdeckung einer auch ohne deren Benennung (chin. ming 名, jap. mei, na), vom Sprechakt unabhängig bestehenden Wahrheit (chin. dao 道, jap. dō, michi).

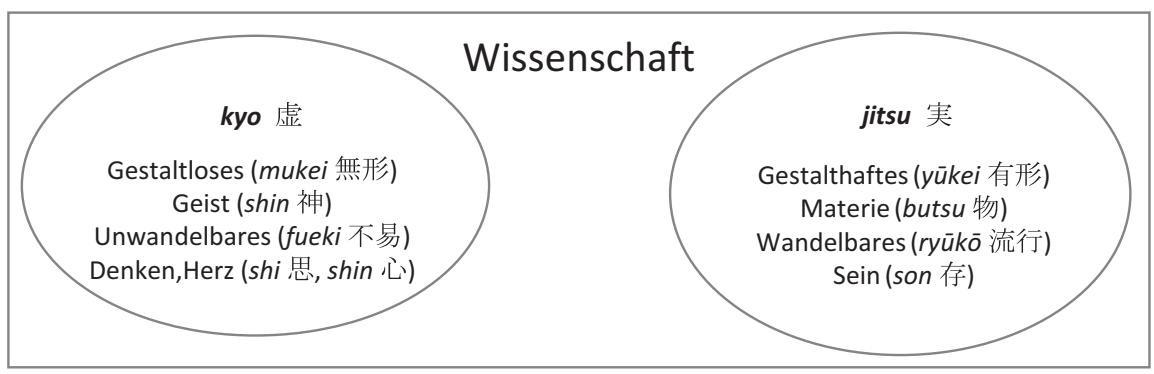

Abbildung 1: Theoretischer Anspruch an wissenschaftliche Texte (schematisch).

Im Gegensatz zum wissenschaftlichen Text deckt in der traditionellen Literaturtheorie der fiktionale Text nicht etwa einen ohnehin bestehenden systematischen Zusammenhang auf, er stellt ihn überhaupt erst her - das ist die Fiktion (Herstellung) im eigentlichen Sinne. Der theoretische Anspruch an den in der folgenden Abbildung 2 schematisierten literarischen Text ist, er möge (bei verschiedener Zweckbestimmung) zwischen den Sphären der „Leere“ und der „Fülle“ vermitteln, er möge also beispielsweise durch Verbalisieren des Gestalthaften (also des sinnenhaft Wahrnehmbaren, etwa des Plätscherns des Wassers eines alten Teichs) auf das nicht verbalisierte Gestaltlose (also das sinnenhaft nicht Wahrnehmbare, etwa die Dimension der Zeit) verweisen.

Der Anspruch der Theorie an die Literatur stellt sich in der japanischen Vormoderne als Postulat einer Substitution dar: Der Text (das Rechteck) deckt vom Signifikanten (jitsu, „Fülle“) und vom Signifikat (kyo, „Leere“) jeweils nur einen Teil ab, deutet also deren Zusammenhang nur an. ${ }^{93}$ Je geringer nun die De-

93 Dass die Modelle in Abbildung 1 und in Abbildung 2 im Grunde mit der von Aristoteles (384-322 v. Chr.) in seiner Poetik entwickelten Aufgabenteilung für die Wissenschaft und die 


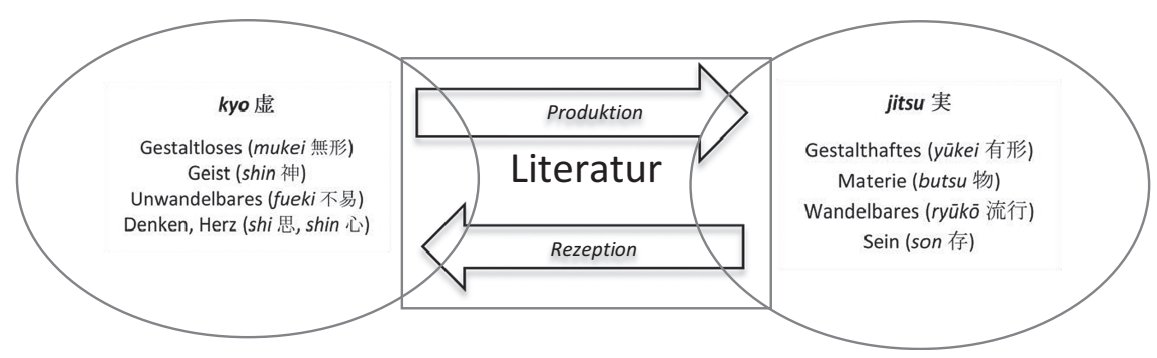

Abbildung 2: Vormoderner theoretischer Anspruch an Literatur (schematisch).

ckungsflächen des Textes (des Rechtecks) mit den Sphären der „Leere“ und der „Fülle“ (Kreise) sind, desto gewichtiger wird der dazwischenliegende Teil des Textes. Der Extremfall des wissenschaftlichen Textes wurde in Abbildung 1 als Inklusion beschrieben. Den Extremfall der bloßen Berührung und gleichzeitig der hundertprozentigen Deckungslosigkeit zwischen den Sphären, also Literatur ohne „Weltbezug“, stellt das folgende Schema dar.

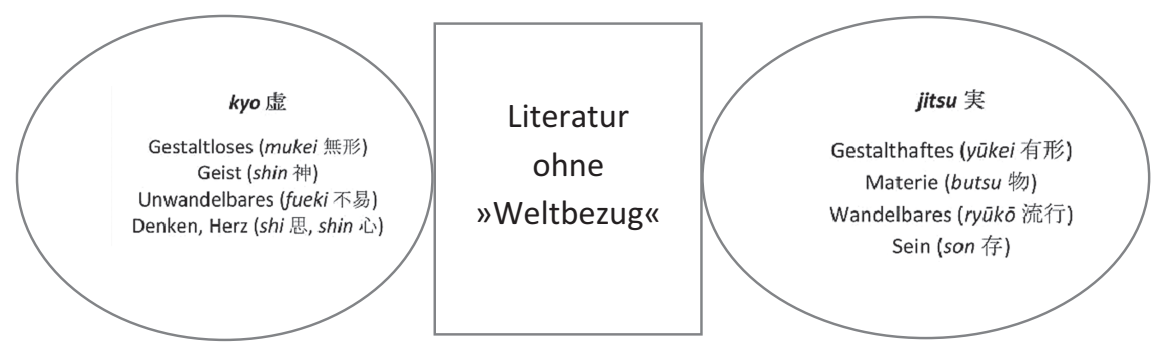

Abbildung 3: Literatur ohne „Weltbezug“(

Es lässt sich leicht vorstellen, warum der in Abbildung 3 dargestellte, rein hypothetische Extremfall in der späten Edo-Zeit von Kritikern und Zensoren der Literatur noch schlechter beurteilt (wenn überhaupt diskutiert) worden wäre als fiktionale Texte, also die Literatur: Er ermöglicht keinen Rekurs auf vorgefundene Gegenstände, ob gestaltlose oder gestalthafte, sondern schafft eine völlig neue und

Poesie (vgl. LimA 2012: 16-28) übereinstimmen, ist mir bewusst. Da die europäische Literaturtheorie von Aristoteles nachhaltig geprägt und wiederum für die Literaturtheorie der Meiji-Zeit prägend ist, ist es nur natürlich, wenn ich im Schlusskapitel der Arbeit auf diesen Umstand zurückkomme. 
nicht durch Riten, kanonische Texte und daraus abgeleitete Verhaltensregeln abgesteckte, behauptete Realität oder Wahrheit (shin 真, dō 道) - kurz: Imagination ist anarchisch und setzt einen autonomen Schöpfer voraus, der im häufig als naturgegeben propagierten Hierarchiesystem der Feudalzeit noch keinen Platz hat. Die weder von der metaphysischen noch von der physischen Seite her substantiierte Vorstellung wird nun in einigen Literaturtheorien mit Wörtern aus dem Feld der Gestaltlosigkeit bezeichnet und der greifbaren Gestalthaftigkeit der realistischen Fiktion gegenübergestellt. Wolfgang Schamoni führt prominente Beispiele hierfür aus Literaturtheorien der späten Edo- und der frühen Meiji-Zeit an. ${ }^{94}$

Gerade weil die hiermit umrissenen drei möglichen Beziehungen zwischen „Leere“ und „Fülle“ (und zwischen den Bestandteilen verwandter Dichotomien) idealtypische Reinformen sind, eignen sie sich zu orientierenden, groben Subsumptionen literaturtheoretischer Texte. Im Lichte der von Georg Lukács (18851971) geführten Erörterung der Widerspiegelung der Welt im Alltagsleben durch Wissenschaft und Kunst wären die in Abbildung 1 schematisierten wissenschaftlichen Sprechakte insofern als „desanthropomorphisierend“ zu sehen, als in ihnen der Mensch keine aktive Rolle bei der Relationierung von Gestaltlosem und Gestalthaftem spielt - die Relation besteht (jedenfalls in der Theorie) ohne ihn. Die künstlerischen Sprechakte (Abbildung 2, Abbildung 3) hingegen wären insofern „anthropomorphisierend“, als sie bei allen Unterschieden im Modus einen Bezug von Künstler und Rezipient zur Welt herstellen. ${ }^{95}$

Dieserart schematisierte Beziehungen der Bestandteile begrifflicher Dichotomien in der Literaturtheorie haben ihre Wurzeln in einschlägigen philosophischen Spekulationen, die im Folgenden als Voraussetzungen der Literaturtheorie pointiert werden sollen - im vollen Bewusstsein dafür, dass sie in den Texten des Kernkorpus dieser Abhandlung nur selten unter Berufung auf deren Quellen und nicht immer so pointiert zum Ausdruck kommen. Wenn wir bei der Suche nach den philosophischen Wurzeln literaturtheoretischer Dichotomien unseren Blick jeweils zuerst nach China und erst dann nach Japan wenden, ist das nur natürlich, denn von China ging die Entwicklung der Philosophie und der Literatur Japans aus, während sich Japan vom 7. Jahrhundert an gegenüber dem politisch, wirtschaftlich und kulturell in Hochblüte stehenden China lange Zeit in der Rolle des Adepten befand..$^{96}$

94 SCHAMONI 1975: 13-14.

95 LuKÁCS 1981 [1963]: 70-190 (Die Eigenart des Ästhetischen, Band 1, Kapitel 1 und 2).

96 BRown 1993. 


\subsection{Totale oder partielle Identität des Leeren und der Fülle}

Das schon erwähnte Zhuangzi (The complete works of Chuang-tzu) wurde in Japan seit dem 8. Jahrhundert und besonders während der Betrachtungszeit der vorliegenden Abhandlung intensiv rezipiert. ${ }^{97}$ Darin bezeichnet $x u$ (aus xushi 虚実, kyojitsu) das nicht Benennbare und darum den Dingen nicht Verhaftete. Shi steht dagegen für alles Benennbare und folglich den Dingen Verhaftete. Das Verhaftetsein in den Dingen verhindert nach Zhuang Zhou den Zugang zum Urgrund aller Weisheit (dao 道), mit anderen Worten: Jeder Versuch einer Benennung führt in die Irre. Am Beispiel der widerstreitenden Thesen von der Existenz oder der Nichtexistenz eines das ganze Universum lenkenden Wesens ${ }^{98}$ erläutert Zhuang Zhou in Kapitel 25 (Ze Yang 則陽) das Verhaftetsein in den Dingen wie folgt.

But wether you say that 'nothing does it' or that 'something makes it like this,' you have not yet escaped from the realm of 'things', and so in the end you fall into error. If 'something makes it like this,' then it is real [shi 害]; if 'nothing does it,' then it is unreal [ $x u$ 虚]. While there are names and realities, you are in the presence of things. When there are no names and realities, you exist in the absence of things. You can talk about it, you can think about it; but the more you talk about it, the farther away you get from it. ${ }^{99}$

97 Ein vollständiger Überblick über diese Diskussion würde den Rahmen der Arbeit sprengen. Für unseren Zweck genügt ein Abriss der die japanische Kultur prägenden Vorstellungen von Gestaltlosem und Gestalthaftem und sich mit ihnen teilweise oder ganz deckenden Begriffswelten. Die wichtigsten verwendeten Quellen der chinesischen Philosophie sind bei (a) den Quellenübersetzungen CHAN 1970 [1963] und DE BARY-BLOOM 1999-I, (b) den Einzelübersetzungen ZHUANG-WATSON 1968 (Zhuangzi), Kong-Wilhelm-VAn Ess 2008 (Sishu) und (c) den Einführungen in die chinesische Philosophie BAUER 2001, RoETZ 1992 und Fung 1983. Zur Zhuangzi-Rezeption siehe Ō 2001; KoHN 1995.

98 Hier werden der Philosoph Jiezi 接子 mit der These von der Existenz eines Lenkers (Ruo Shi 或使, im Zhuangzi ,something makes it like this“), der Philosoph Ji Zhen 季真 mit der These von der Nichtexistenz eines Lenkers des Universums (mo wei 莫為, im Zhuangzi „nothing does it") zitiert.

99 ZHUANG-WATSON 1968: 229-293. Originaltext: 或之使、莫之為、未免於物、而終以為過。或 使則實、莫為則虛。有名有實、是物之居、無名無實、在物之虛。可言可意、言而愈疏。

(Zhuangzi zhu 莊子注 8: 41b-42a, SKQS-Edition). Aus der amerikanischen Übersetzung von Victor Mair übersetzt Stephan Schumacher die Passage wie folgt: „Da bedingte Verursachung und Nichtfaktizität / nicht von der Vorstellung von Dingen frei sind, / führen sie zum Irrtum. Gehen wir aus von einer Bedingten Verursachung, / so kommen wir zur Realität; / gehen wir aus von der Nichtfaktizität, / so kommen wir zur Abwesenheit. / Wo es Namen gibt und Realität, da wohnen wir im Reich der Dinge; / wo es weder Namen gibt noch Realität / da existieren wir in der Abwesenheit der Dinge. Wir können zwar reden, können denken, / doch je mehr wir reden, / desto weiter sind wir von der Sache entfernt“ (ZHUANG-MAIR-SCHUHMACHER 1998: 367). 
Hier manifestiert sich eine Wertung der Versprachlichung, die in zahllosen Varianten und Wiederholungen die Literaturtheorie in China und Japan durchzieht: Was versprachlicht wird, sei nur Stellvertreter, nicht aber der tatsächliche Wesenskern, der sich eben nicht versprachlichen lasse. Hiernach kann es nicht verwundern, wenn Zhuang Zhou generell die Dichotomien wesentliche Dualität aufzuheben sucht. Zhuang nimmt „Fülle“ und „Leere“ zwar getrennt wahr, hält die beiden aber, wie die folgende Passage zeigt, für identisch.

The „this“ is also the „that“. The „that“ is also the „this“. The „this“ has one standard of right and wrong, and the „that“ also has a standard of right and wrong. Is there really a distinction between „that“ and „this“? When „this“ and „that“ have no opposites, there is the very axis of Tao. Only when the axis occupies the center of a circle can things in their infinite complexities be responded to. The right is an infinity. The wrong is also an infinity. Therefore I say that there is nothing better than to use the light (of Nature). ${ }^{100}$

Auch die im japanischen Geistesleben einflussreichen Schriften der chinesischen Tiantai 天台 -Schule des Buddhismus tendieren zur von Zhuang Zhou postulierten Identität von Absolutheit und Erscheinung - allerdings nicht so radikal wie jener. In den „Drei Wahrheiten“ (sandi 三諦) der Tiantai-Schule sind enthalten: (1) die Wahrheit des Scheins (jiadi 仮諦) als die niedere weltliche Wahrheit, (2) die Wahrheit der Leere (kong di 空諦), gleichzeitig das Illusionäre im Sein und das Absolute, und (3) zhong di 中諦, die Wahrheit der Mitte zwischen Schein und Leere. Das bedeutet „im Kleinen, dass in dem momenthaften Aufblitzen eines jeden dharma [Trägers] in der Erscheinungswelt immer auch seine wahre, „leere“ Natur zum Zuge komme, und im Großen, dass es zwischen dem wahren und dem empirischen Sein [...] überhaupt keinen Unterschied gebe, sondern dass beide Sphären gewissermaßen ineinander stehen. “101 Dazu passt ein bekanntes Schlagwort der Tiantai-Schule: „In jedem Staubkorn, in jedem Augenblicksgedanken sind alle dreitausend Welten enthalten.“102 Enthaltensein meint aber - und hier liegt der Unterschied zum zuvor zitierten Zhuang Zhou - nicht deren totale Identität, sondern deren „nur“ partielle Deckung.

Als weitere einflussreiche Identitätsphilosophie ist schließlich der Chan 禅 (im japanischen Zusammenhang „Zen-“) Buddhismus zu nennen. Er betont stärker als alle anderen buddhistischen Schulen die Meditation und wertet ihr gegenüber

100 CHAN 1970 [1963]: 183. Wie schon erwähnt, verweist Chan in seinem Kommentar auf die verblüffende Ähnlichkeit der Philosophie Zhuang Zhous mit dem Identitätskonzept bei Hegel.

101 BAUER 2001: 213-215.

102 BAUER 2001: 213-215. 
die verbale Festlegung zentraler Aussagen und Begriffe ab - darin Zhuangs Abwertung des Sprechaktes ähnlich. Ziel der Meditation des Chan-Buddhismus ist das unmittelbare Erlebnis der Leerheit, das im Gegensatz zu anderen buddhistischen Meditationsformen weniger die Beruhigung und Konzentration als vielmehr die Nichtung der Gedanken und Gefühle erwirken sollte. Das Erkenntnisziel der chan-buddhistischen Philosophie ist es, das $\mathrm{zu}$ empfinden, was in anderen buddhistischen Schulen verstanden werden soll: das Zusammenfallen von Erscheinungswelt und wahrer Welt. ${ }^{103}$

Der dieserart umrissenen Vorstellung totaler oder partieller Identität dichotomisch bezeichneter Referentia stehen die im Folgenden zusammengefassten Vorstellungen totaler oder partieller Differenz gegenüber.

\subsection{Totale oder partielle Differenz in der Dichotomie „Geist - Materie“ als Wurzel der Dichotomien „Dynamik - Statik“ und „Unwandelbares - Wandelbares“}

Als begriffliche Wurzel der literaturtheoretisch eminent wichtigen Dichotomien „Dynamik - Statik“ sowie „Unwandelbares - Wandelbares“ sind die Begriffe „Geist“ und „Materie“ zu sehen. In der neokonfuzianischen Philosophie des Zhu Xi wird der Begriff „Geist“ durch li 理 („Prinzip“) versprachlicht, „Materie“ durch $q i$ 気 („Äther“). ${ }^{104}$ Quelle ist dabei das Yijing 易経 (The I Ching, [Leitfaden der Wandlungen]), das aber nicht nur Kernstück des klassischen konfuzianischen Kanons ist, sondern auch von den Daoisten hoch geschätzt wurde. Die Entstehungszeit des Textes liegt im Dunkel der Legende und wird teilweise bis ins 3. Jahrtausend v. Chr. zurückverlegt. Auch die Entstehungszeit des die Divination anleitenden Teils und die Autorschaft der Kommentare sind letztlich nicht geklärt. Dass beide Teile seit dem Ende des 6. Jahrhunderts v. Chr. als kanonisiert gelten dürfen, als auch die ersten ethischen Interpretationen des Yijing entstanden, hat sicherlich dazu beigetragen, die Autorschaft ganz oder teilweise (jedenfalls aber fälschlich) dem gleichzeitig lebenden Philosophen Kongzi 孔子 (551479 v. Chr.), also dem „Urvater“ des Konfuzianismus, zuzusprechen. ${ }^{105} \mathrm{Zu}$ den Begriffsfeldern „Geist“ und „Materie“ wird in den Kommentaren das Folgende ausgeführt.

103 BAUER 2001: 224.

104 Bezüglich des Zusammenhangs mit anderen Termini siehe Anm. 81.

105 Shaughnessy 1993: 216-228. 
Essence and material force ( $c h ' i)$ are combined to become things. The wandering away of spirit (force) becomes change. From this we know that the characteristics and conditions of spiritual beings are similar to those of Heaven and Earth and therefore there is no disagreement between them. The knowledge [of spirit] embraces all things and its way helps all under heaven, and therefore there is no mistake. It rejoices in Nature (T'ien, Heaven) and understands destiny. ${ }^{106}$

Der Neokonfuzianer Zhu Xi ist nicht der erste, sicherlich aber einer der für Japan wichtigsten chinesischen Philosophen, welche diese Anschauung weiterentwickelten. Zhu Xi hält die Sphären von „Prinzip“ und „Äther“ deutlich voneinander getrennt und versteht unter dem Prinzip li die Einheit allen Seins, die vor jeder Dualität der Energien yin und yang Bestand hatte. Zhu Xi nennt dieses li als Ureinheit auch das „sehr große Äußerste“ (chin. taiji 太極). Aus dieser Ureinheit entwickele sich der „Äther“ als Urenergie, die im Zusammenwirken mit dem „Prinzip“ alles Existierende hervorbringe. Wichtig ist nun im Hinblick auf die Theorie der Literatur, die ja nicht nur als gesellschaftliche Erscheinung, sondern zunächst einmal als Hervorbringung eines Individuums gesehen wird, wie Zhu Xi die Sphären „Prinzip“ und „Äther“ in Beziehung zum Individuum setzt: beide seien in jedem Menschen enthalten, doch während das „Prinzip“ als angeborene (benran 本然, „Original Nature“) Natur (xing 性) immer gleich bleibe, sei der „spezifische Äther“ (qizhi 気質, „Specific Ether“) individuell verschieden.

The Specific Ether of a sage is completely pure and clear, so his Original Nature appears in its entirety. But an ordinary person has a more or less turbid Specific Ether, giving rise to the various human desires. These desires conceal and obstruct the Original Nature and produce human evil. That is to say, Original Nature based on Principle (absolute good), is more deeply rooted than Specific Ether, based on Ether (relative good and evil). Anyone who can remove the impure and turbid tendencies from his Specific Ether will be able to restore his Original Nature. ${ }^{107}$

Ein von der praktischen Ethik des Zhu Xi auch nur indirekt geprägtes Denken so viel können wir schon jetzt ahnen - spricht der Literatur das Potenzial (qi) $\mathrm{zu}$, entweder die Wirkung der angeborenen (guten) Natur ihres Verfassers und seiner Leser zur Entfaltung zu bringen, oder die gute Naturanlage im Gegenteil durch negative Ausprägung des „spezifischen Äthers“ zu verschütten. Dieses Potenzial bestimmt thematisch das Denken auch der (neo-)konfuzianischen ja-

106 CHAN 1970 [1963]: 265. Chan kommentiert, dass nicht klar sei, was genau „spirit“ (guishen 鬼神) sein solle. Sicher sei nur, dass damit nicht der auf menschliche Angelegenheiten einwirkende Geist eines Verstorbenen gemeint ist, sondern eher eine gestaltlose Wirkkraft von Transformationen (CHAN 1970: 266).

107 Maruyama-Hane 1974: 23. 
panischen Denker des 17. bis 19. Jahrhunderts. Als unorthodoxer Vertreter des japanischen Neokonfuzianismus gilt Ogyū Sorai 荻生徂徠 (1666-1728). Sorai gehört ursprünglich zu den Vertretern der neokonfuzianischen Zhu-Xi-Schule, ist aber in der Philosophiegeschichte als Hauptvertreter der „Fraktion der Studien der alten Schriften“ (kobunji gakuha 古文辞学派) vor allem bekannt für seinen Angriff auf den Sprachgebrauch der Neokonfuzianer seiner Zeit, denen er vorwarf, die alte Sprache der sechs chinesischen Klassiker des Konfuzianismus ${ }^{108}$ nicht mehr $\mathrm{zu}$ verstehen und sie anhand einer unangemessenen weil neuen Sprache falsch zu interpretieren. Dieser Angriff steht in der Sorai-Forschung meist im Vordergrund, und in der Tat sind Sorais diesbezügliche Ansicht und sein Kongzi nachempfundener Anspruch, nicht mehr zu tun, als das dao der heiligen Urkaiser zu tradieren, ${ }^{109}$ wichtige Punkte seines in der EdoZeit einflussreichen Denkens. Doch in unserem Zusammenhang ist Sorais an Itō Jinsai 伊藤仁斎 (1627-1705) angelehnte Ontologie von besonderem Interesse: Nicht eine transzendentale Idee, sondern eine aktive Kraft treibe die statischen Elemente der Realität an. ${ }^{110}$ Und weil - hier im Unterschied zu Jinsai - das Gute der menschlichen Natur nicht angeboren sei, könne es nicht einfach nach außen befördert werden, sondern müsse durch das Studium klassischer chinesischer Literatur und Kultur erreicht werden. Was Jinsai „Tugend“ (toku 徳) nennt, sei lediglich das Konzept (mei 名), nicht aber die „Substanz“ (jitsu 実) der Tugend. Die angeborene Anlage des Menschen (shitsu 質) müsse durch literarische Formen und Riten der goldenen Zeit der „Drei Zeitalter“ (sandai 三代, die teilweise mythischen Anfänge der chinesischen Historie bis zum Ende der Zhou-Dynastie im Jahr 256 v. Chr.) in eine verfeinerte Form (bun 文) gebracht werden. Im Benmei (Distinguishing Names, 1717) ${ }^{111}$ führt Sorai dazu das Folgende aus.

„Comprehending the way“ means comprehending the way of the early kings, that is, unifying it completeley so that no aspect is neglected. For this reason, such people who fully comprehend the way of the early kings are rare: Confucius' observation „The writer of this poem must have understood the way“ [Mengzi 2 A / 4] indicates this rarity. „Knowing the rites“ refers to understanding the rites of the early kings. „Fathoming words“ means understanding the early kings' way of using words. „Rites“ and „words“ are divisions of the way.

108 Yi jing (Book of Changes), Shu jing (The Book of Documents), Shi jing (The Book of Odes), Li ji (The Book of Rites), Chun qiu (The Spring and Autumn Annals), Zhou li (The Rites of the Zhou). 109 In Abschnitt 7.1 des Lunyu heißt es: 子曰、述而不作。信而好古。霢比於我老彭。(Lunyu zhushu 論語注疏 7: 1a, SKQS-Edition). „As a transmitter and not a maker, believing in and loving the ancients, I venture to compare myself with our old Pang.“ (LEGGE 1900 [5. Jh. v. Chr.]: 78). „Pang“: ein Gelehrter der Yin 殷-Dynastie (ca. 1700- ca. 1100 v. Chr.).

110 YAMASHITA 1997: 142-150.

111 Originaltext in NST 36: 48-53 (japonisierte Version), 212 (Originalversion). 
Such distinctions are made in order to facilitate learning. The early kings' teachings are expressed in the words of the Book of Poetry, Book of History, Book of Rites, and Book of Music. The Poetry and History are „repositories of ritual principles“. By understanding the words of those texts, we understand ritual principles. By understanding rites and ritual priciples, we come close to exhausting the way of the early kings. ${ }^{112}$

Im Licht dieses Zitates aus Kapitel IV des Benmei besteht für Sorai die Aufgabe der Kultur im Allgemeinen und damit auch der Literatur im Besonderen darin, die immaterielle Substanz (jitsu) der Tugend (des dao) in verfeinerter Form zu materialisieren. Bemerkenswert ist dabei die Verwendung des Wortes jitsu 実 zur Bezeichnung des Immateriellen als Realität, die eigentliche Substanz: Diese Interpretation steht dem schon damals üblichen umgangssprachlichen Gebrauch des Ausdrucks diametral gegenüber. Wenig später dehnt Sorai seine Argumentation im Sorai sensei tōmon sho 徂徠先生答問書 ([Aufzeichnungen von Lehrgesprächen des Meisters Sorai], 1725) aus. Literatur, insbesondere in Form von Gedichten und Essays, sei in der Lage, das Verständnis für die Sitten einer Zeit und eines Landes sowie für menschliche Gefühle zu vertiefen: „Von einem hohen Rang aus weiß man [dann] auch über die niedrigen Leute Bescheid, der Mann lernt das Gemüt der Frau kennen und der Kluge versteht die Sinnesart des Törichten." ${ }^{113}$ Wir erinnern uns hier sofort an die eingangs in Gruppe A zitierten Texte mit ihrem Blick auf den didaktischen Wert der Literatur als Vermittlerin des Verständnisses für Handlungsmotive und Moral der Menschen.

In seinem Yume no shiro 夢之代 ([Anstelle von Träumen], 1802-20) nimmt auch der neokonfuzianische Gelehrte Yamagata Bantō 山片蟠桃 (1748-1821) Bezug auf die Philosophie des Zhu Xi, doch geht er über dessen Kanon, über chinesische und japanische Exegesen weiterer Texte der akademischen und literarischen Tradition Chinas weit hinaus und bezieht auch Quellentexte des Shintō zu

112 Benmei, Kapitel IV (Chi 智): Dō wo shiru to wa, sen'ō no dō wo shiru nari. Kore sono subete wo subete kore wo ii, fukumazaru tokoro nashi. Yue ni sono hito wo katanzu. Kō Shi iwaku: ,Kono shi wo tsukuru mono wa, sore dō wo shiru ka' to wa, katanzuru no ji nari. ,Rei wo shiru' to wa, sen'ō no rei wo shiru nari. ,Gen wo shiru' to wa, sen'ō no hōgen wo shiru nari. Kono nisha wa, dō no bun nari. Wakachite kore wo iu wa, gakusha ni ben suru yuen nari. Sen'ō no oshie wa, Shi Sho Rai Gaku ni shite, Shi Sho wa gen nari, gi no fu nari. Gen wo shireba sunawachi gi wo shiru. Rei to gi to wo shireba, sunawachi dō wa motte tsukusu beki ni chikashi. 知道者。知先王之道也。是統其全言 之。無所不包。故難其人焉。孔子曰。為之詩者。其知道乎。難辞也。知礼者。知先王之礼 也。知言者。知先王之法言也。之二者。道之分也。分而言之。所以便学者也。先王之教。詩 書礼楽。詩書言也。義之府也。知言則知義。知礼与義。則道庶幾可以尽焉。(NST 36: 219; Japonisierung nach NST 36: 58-59). Übers. OGYŪ-TUCKER 2006 [1717]: 192.

113 SCHAMONI 1975: 13, Anm. 10. Original: NKBT 94: 169. 
den Themenfeldern „Wirklichkeit“ und „Geist der Sprache“ aus der japanischen Philosophie der „Landesstudien“ in sein Denken ein. Er versucht also nichts Geringeres als eine Integration unterschiedlichster Quellen und Spuren chinesischer und japanischer Philosophie in der Edo-Zeit in sein Denken. ${ }^{114}$ In Bezug auf den Geist (jap. shin 神) beschreibt Bantō in Yume no shiro seinen Erfahrungsraum als die gesamte Wirklichkeit (jitsu 実), als „[...] die sinnenhaft erfahrbare Welt des ,wachen Menschen“."115 Die daoistische Symbolik lehnt er als eskapistisch ab, sieht das Götterzeitalter-Kapitel des Nihon shoki (720, Chronicles of Japan) $)^{116}$ als Traum im Traum, als Lüge in der Lüge (bōchū no mō 妄中の妄), als Leere in der Leere (kyochū no kyo 虚中の虚) an und stellt sich damit auch gegen jene dem Neo-Shintōismus nahestehenden Denker der „Landesstudien“ wie Motoori Norinaga. „Nur die Annahme der Wirklichkeit in ihrer Beschränkung auf den Kern des Kommunizierbaren, des ,Glaubhaften, da Beweisbaren‘, bildet die Voraussetzung eines Handelns, das dem Prinzip der ,öffentlichen Verantwortung‘ (giri) Rechnung trägt.“117 Die von Bantō zur Verteidigung dieses seines Wirklichkeitsverständnisses eingesetzten Formulierungen (aufgelistet in KRACHT 1986: 283, Anm. 229) antizipieren in bemerkenswerter Dichte den Grundwortschatz literaturtheoretischer und -kritischer Texte, die ein halbes Jahrhundert nach seinem Yume no shiro entstanden sind. Das Denken Bantōs weist allerdings eine weitere Besonderheit auf: Er folgt nämlich der von Zhu Xi zitierten These, dass die sittliche Einstellung der „Wahrhaftigkeit“ (cheng 誠) (im konkreten Fall beim Opferritus) ihrerseits „Wirklichkeit“ (shi 実) bewirke, indem die Geister des Himmels und die Geister der Menschen dann anwesend seien. Hier wird wenigstens im Bereich der Ethik durch die Gegenüberstellung der „Wirklichkeit der Dinge“ und der „Wirklichkeit des Herzens“ die Einheit der Wirklichkeit grundsätzlich in Frage stellt. $^{118}$

Auch die „Landesstudien“ der Edo-Zeit neigen der Vorstellung einer totalen oder partiellen Differenz von sprachlich Bezeichnendem und dem sprachlich Bezeichneten zu. Das nimmt nicht wunder, wenden die „Landesstudien“ sich doch gegen die wegen ihrer Herkunft aus Indien und China als Fremdkörper wahrgenommenen Weltanschauungen des Buddhismus und Daoismus, unter

114 KRACHT 1986 gibt an, dass die der Abhandlung vorangestellte Liste der zitierten Werke 375 Titel umfasst (237).

115 KRACHT 1986: 237.

116 Moderner Nachdruck in NKBT 67-68, englische Übersetzung: AsTON 1978 [720]. Das „Götterzeitalter“ (Shindai 神代)-Kapitel beschreibt den prähistorischen Mythos von der Entstehung der Götter und deren Schöpfung Japans (NKBT 67: 76-187; ASTON 1978 [720]: 1-108).

117 KRACHT 1986: 237-238.

118 KRACHT 1986: 238-239. 
deren Einfluss die Vorstellung totaler oder partieller Identität von „Leere“ und „Fülle“ sich in Japan verbreitet hatten. Als autochthon intendierte Philosophie opponieren die „Landesstudien“ gleichzeitig auch gegen den Konfuzianismus und seinen Quellenkanon und betonen demgegenüber die philologische Erforschung altjapanischer Literatur im weitesten Sinne, insbesondere des Kojiki 古事 記 (Aufzeichnung alter Begebenheiten, ca. 712) und der Lyrikanthologie Man'yōshū 万葉集 (The Ten Thousand Leaves, Ende 8. Jh.). Im Mittelpunkt der auf die Sprache bezogenen Überlegungen stehen hier Wörter wie makoto („Wahrhaftigkeit“, „Wahrheit“, „Wirklichkeit“) und kotodama („Geist der Sprache“) ${ }^{119}$ und werden für eine Restaurierung des autochthonen Japanischen und eine Rückkehr der Schriftgelehrsamkeit zur Lebenswirklichkeit des gemeinen Volks ins Feld geführt. Dieses Bestreben beinhaltet nicht nur eine Defragmentierung der durch konfuzianisch geprägte Rollenfestschreibungen zerklüfteten japanischen Gesellschaft, sondern auch eine Infragestellung offiziell sanktionierter Formen des Schrifttums ${ }^{120}$ und vor allem der Festschreibung der Identität zwischen Bezeichnendem und Bezeichneten. ${ }^{121}$ Freilich sind die Gelehrten der „Landesstudien“ weder mit dem Rekurs auf Urstadien der Sprache noch in der Kritik eines zu großen Abstandes zwischen Signifikant und Signifikat in der Sprache ihrer Zeitgenossen allein: Namentlich die konfuzianischen Gelehrten der kogaku 古学 („Alte Studien“)Schule wie der erwähnte Ogyū Sorai stimmen in beiden Punkten mit den Gelehrten der „Landesstudien“ prinzipiell überein. ${ }^{122}$ Einer der wesentlichsten Unterschiede besteht aber darin, dass Letztgenannte durch die Betonung der Rolle der menschlichen Stimme vor allem der Poesie und dem Lied die Fähigkeit zusprechen, die Intentionen des Geistes auszudrücken. ${ }^{123}$

Wir haben nun drei logisch mögliche Beziehungen zwischen den in literaturtheoretisch einschlägigen Dichotomien enthaltenen Gegenständen gesehen

119 HISAMATSU 1952: 319-329.

120 HaROOTUNIAN 1988: 37.

121 „In eighteenth-century Japan the managerial class sought to establish a ,supraclass“ and, thus, convey an eternal character to the ideological sign. This aim was represented best by the Neo-Confucian insistence on identifying words with what they were meant to denote in order to extinguish or suppress by driving inward any possibility of conflict between fixed social judgments and any effort to endow one sign with several meanings. Ideological hegemony consisted of making the sign , uniaccentual'. Until the eighteenth century, this kind of linguistic hegemony had been able to enforce a certain uniformity in presentation - even though ,spoken language' was beginning to find its way into texts of popular verbal fictions - by forcing the sign to withdraw from the pressures of struggle over accent and meaning." (HAROOTUNIAN 1988: 43).

122 Siehe HaROOTUNian 1988: 44-45.

123 Harootunian 1988: 45-46. 
und - in der gebotenen Kürze - Beispiele für deren Realisierung in Denkmodellen der Identität und Differenz genannt. Die Denkmuster bilden die Außengrenzen des philosophischen Feldes, in dem japanische Literaturtheorien von den Anfängen bis 1850 als Teilfeld zu verorten sind und grundsätzlich als Varianten der aufgezeigten Muster gesehen werden sollen.

\subsection{1 „Wahrheit und Idee“ in der uneigentlichen Rede der Dichtung: Der Realismus-Begriff am Beispiel des Wenxin diaolong (ca. 520)}

Das Wenxin diaolong 文心雕龍 (The Literary Mind and the Carving of Dragons, ca. 520) ist die erste literaturtheoretische Monografie Chinas. In Japan ist sie seit etwa 891 bekannt und wird bis heute intensiv rezipiert. ${ }^{124}$ Ihr Verfasser ist Liu Xie 劉諰 (465-522), der in seinem Werk vor allem literarische Traditionen zusammenfasst und deren natürliche Schlichtheit gegen den in seinen Augen überladenen Stil seiner Gegenwart verteidigt. In Teil I (Kapitel 1 bis 5) legt Liu Xie grundsätzliche Überlegungen dar und fordert, dass jede Literatur die Klassiker des Konfuzianismus zu ihrer Basis macht. Teil II (Kapitel 6 bis 25) behandelt die gängigen reimenden und nichtreimenden Textsorten in Ursprung, Funktion und Charakteristika. In Teil III (Kapitel 26 bis 49) beschäftigt sich Liu mit Bedingungen und Techniken literarischer Produktion. In diesem Teil behandelt Liu Xie die Begriffe „Fiktion“ und „Wirklichkeit“ (und ihre Varianten) am eingehendsten. Thematisch einschlägige und auch für die japanische Literaturtheorie grundlegende Passagen daraus sollen im Folgenden aus der Übersetzung von Vincent Yuchung Shih zusammengefasst werden. ${ }^{125}$

124 In Japan erwähnt wird das Wenxin diaolong erstmals im von Fujiwara no Sukeyo 藤原佐 世 (874-898) erstellten Nihonkoku genzai shomokuroku 日本国見在書目録 ([Verzeichnis der in Japan existierenden Schriften], ca. 891), dem ältesten Verzeichnis von in Japan gehaltenen chinesischen Schriften. Das Bunkyō hifu ron (810-824; S. 81) zitiert indirekt aus dem Wenxin diaolong. Weitere Verbreitung fand das Wenxin diaolong (dann sinojapanisch Bunshin chōryū gelesen) als japanische Bearbeitungen (wakokubon 和刻本) des chinesischen Arztes Zhang Suichen 張遂辰 (1589-1668) und des japanischen konfuzianischen Gelehrten Oka Hakku 岡白 駒 (1692-1767) aus dem Jahre 1731. Einen modernen Nachdruck bieten 1987 in der 8. Auflage die Bände SSKT 64-65.

125 Teil IV besteht aus nur einem, dem abschließenden Kapitel 50, in dem Liu seine Motivation zum Verfassen des Wenxin diaolong darlegt. Als Originalquelle werden im Folgenden SSKT 64 und 65 verwendet. Beim Vergleich mit dem Original und LiU-SHIH 1959 [520] erweist sich die deutsche Übersetzung LIU-LI 2007 [520] wegen zahlreicher Ungenauigkeiten als unbrauchbar. 
In Kapitel 26 (Shensi 神思, Spiritual Thought or Imagination) idealisiert Liu Xie die kontemplative Haltung, die den Dichter bereit für die Aufnahme der Zehntausend Welten (der Realität) mache. Darauffolgend behandelt er die Beziehung von Geist (shen 神) und Denken (si 思) näher.

Through the subtlety of the imagination, the spirit comes into contact with external things. The spirit resides in the mind, and the key to its secret is controlled by both the feelings and the vital force. Physical things reach our minds through our ears and eyes, and the key to their apprehension is the skilled use of language. When the key works smoothly, there is nothing which will not appear in its true form; but when its operation is obstructed, the spirit looses its rationale. For this reason vacancy and tranquility are important in the development of literary thinking: the achievement of this state of vacancy and tranquility entails the cleaning of the five viscera and the purification of the spirit. One has also to acquire learning in order to maintain a store of precious information, and to contemplate the nature of reason so as to enrich his talents; he must search deeply and experience widely in order that he may exhaustively evoke the source of light; he must master literary traditions in order to make his expressions felicitious and smooth. ${ }^{126}$

Damit sind die Haltung des Dichters als „vakanter“, offener Empfänger der Wahrheit und das Ziel, die Dinge in ihrer wahren Form erscheinen zu lassen, vorbereitet. Was nun im Wenxin diaolong den Dichter zum Dichten bewegt, welches Material er verarbeiten und welche Sprache er einsetzen soll, schildert beispielsweise Kapitel 31 (Qingcai 情采, Emotion and Literary Expression), das mit einer Darlegung der divergierenden Ansichten der daoistischen Philosophen Laozi und Zhuang Zhou zum Wert schöner Sprache beginnt. Liu favorisiert Laozi wegen dessen Misstrauen gegenüber der äußeren Schönheit von Formulierungen und führt dann aus:

Cosmetics are used to beautify the complexion, but the enchanting appeal in the look is born of natural beauty; similarly the function of literary decorativeness is to adorn discourse, and beauty of eloquence is based on real emotion. Therefore emotion is the warp of literary pattern, linguistic form the woof of ideas. Only when the warp is straight can the woof be rightly formed, and only when ideas are definite can linguistic form be meaningful. This is the fundamental principle in literary creation. The Ancient Poets, in writing their poems, built their literary forms on emotion, while later poets, in writing their fu [賦] and sung [頌; = song], ${ }^{127}$ created emotion to fit literary forms. How do we know this is so? Because the rise of the feng

126 LIU-SHIH 1959 [520]: 154-155. Originaltext: 故思理為妙、神與物遊。神居胸臆、而志氣統其 關鍵、物沿耳目、而辭令管其樞機。樞機方通、則物無隱貌、關鍵將塞、則神有遯心。是以陶 鈞文思、貴在虛靜。疏淪五藏、澡雪精神、積學以儲寶、酌理以富才、研閱以窮照、馴致以懌 辭。(Wenxin diaolong 文心雕龍 6: 1a, SKQS-Edition).

127 In Kapitel 8 des Wenxin dialong wird das fu als direkter (nicht in einer Metapher oder anderer uneigentlicher Rede verkleideter) Ausdruck von Emotionen gegenüber den Dingen beschrieben. (LIU-SHIH 1959 [520]: 45). Das sung [= song] beschreibt Kapitel 9 des Wenxin dialong 
[風] and $y a$ [雅] ${ }^{128}$ was due to the fact that the Ancient Poets, full of real emotions and opinions, sang of these emotions and opinions in satirical remonstrances against their superiors: this is what is meant by building literary forms on emotion. The philosophers, on the contrary, felt no real frustration, but indulged in exaggerated ornamentation merely for the sake of winning fame and fishing for worldly glory: this is what is meant by creating emotion to fit a literary form. A literary piece will be pertinent, simple, and realistic, if it is based on feelings; but if it aims merely at literary achievement, though it may have deceptively alluring charm, it will be prolix and diffuse. ${ }^{129}$

Wie schließlich das Hauptmaterial der Dichtung verarbeitet werden soll, beschreibt Liu Xie unter anderem in Kapitel 36 (Bixing 比興, Metaphor and Allegory). Im Zusammenhang mit den auf den Seiten 4-4 dargestellten logischen Möglichkeiten einer Verbindung von Signifikant und Signifikat ist daraus insbesondere die Definition des von Shih mit metaphor übersetzten Wortes bi 比 („Nebeneinanderstellen“) von Interesse.

What do we really mean by $p i$ [= bi 比]? A description of things used to stand for ideas, and the use of figures of speech to intimate the nature of certain facts. Thus gold and pewter are used to stand for illustrious virtue, a jade tally signifies an outstanding man, a caterpillar means education, cicadas and grasshoppers denote howling and shouting, washing clothes symbolizes sadness of heart, and the rolling up of a mat is used as a figure for firmness of will: these illustrate the meaning of the $p i^{130}$

Ein in dreifacher Hinsicht bemerkenswerter Passus! Erstens werden hier Dinge ( $w u$ 物, mono), Ideen ( $y i$ 意, $i$, ,ideas“) und Sachverhalte (shi 事, koto, „certain facts“) als Gegenstände des literarischen Textes deutlich voneinander getrennt. Zweitens differenziert Liu die verschiedenen Aspekte des Verfassens literari-

als Loblied auf mutige Taten und Beschreibung der entsprechenden Lobesriten (LIU-SHIH 1959 [520]: 50).

128 Feng: aus verschiedenen Regionen gesammelte Volkslieder und Volksliedtexte; $y a$ : Liedtexte und narrative Texte eleganteren Stils (LIU-SHIH 1959 [520]: 26, Anm. 2).

129 LIU-SHIH 1959 [520]: 176-177. Originaltext:. 夫鉛黛所以飾容、而盼倩生於淑姿、文采所以飾 言、而辯麗本於情性。故情者文之經、辭者理之緯。經正而後緯成、理定而後辭暢。此立文之 本源也。昔詩人什篇、為情而造文、辭人賦頌、為文而造情。何以明其然。蓋風雅之興、志思

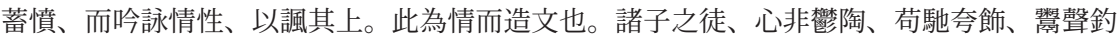
世、此為文而造情也。故為情者要約而寫真、為文者淫麗而煩濫。 (Wenxin diaolong 文心雕龍 7: 1b-2a, SKQS-Edition).

130 LIU-SHIH 1959 [520]: 196. Originaltext: 且何謂為比。蓋寫物以附意、颮言以切事者也。故金 錫以喻明德、珪璋以譬秀民、蛽蛉以類教誨、蜩螗以寫號呼、澣衣以擬心憂、席卷以方志固。凡 斯切象、皆比義也。 (Wenxin diaolong 文心雕龍 8: 1b, SKQS-Edition). Zur Phrase „rolling up of a mat“ merkt Shih an: „Actually, the line runs: ,My heart is not a mat, you can not roll it.‘ Rolling up a mat would seem to connote the opposite of firmness. But in classical allusions, Chinese scholars often quote out of context, and expect the reader to understand the meaning by referring in his own mind to the original context and the original meaning“ (LIU-SHIH 1959 [520]: 196). 
scher Texte: Der Sprechakt (yang yan 颺言, jap. koto wo agu im Sinne von „das Wort erheben“) erfüllt nicht nur die Funktion des direkten „Abbildens“ (xie 写, jap. utsusu) oder „Imitierens“ (ni 擬, jap. gi su), sondern wahlweise auch die Funktion des direkten Vergleichs (fang 方, jap. kurabu, „vergleichen“ oder „gleichsetzen“) oder des substituierenden Exemplifizierens ( $y u$ 喻 und pi 譬, tatou, „Beispiele geben“ sowie lei 類, jap. rui su, „,analogisieren“). ${ }^{131}$ Und drittens sei der Sprechakt dazu angetan, „Ideen beizugeben“ (fu yi 附意, jap. $i$ wo fu su), „mit dem Sachverhalt übereinbringen“ (qie shi 切事, jap. koto ni setsu ni suru) oder „zum Abbild zu passen“ (qie xiang 切象, jap. shō ni setsu nari). ${ }^{132}$ „Beigeben“ und „Passen“ sind nicht Akte der für die Metapher charakteristischen Substitution oder Akte des Vergleichs, sondern vielmehr der Erweiterung. Es ergibt sich daraus, dass Liu mit bi mehr als nur den expliziten Vergleich, nämlich die Gleichsetzung, meinen muss. ${ }^{133}$

\subsubsection{Das Gegenständliche (die „Fülle“) und das Formlose (das „Leere“) am Beispiel des Santi shi (ca. 1250)}

Ein weiterer chinesischer Protoyp philosophienaher japanischer Literaturtheorien ist das Santi shi 三体詩 ([Dichtung in dreierlei Gestalt], 1250), weil der Text einerseits repräsentativ ist für diejenige chinesische Dichtungstheorie, die mit den meta-

131 Jürgen Link beschreibt die Metapher als die Substitution eines synthetischen Signifikanten durch einen anderen synthetischen Komplex, womit die Metapher vom Vergleich als einer partiellen Überlappung deutlich zu unterscheiden ist (LINK 1985 [1974]: 149). Dass Vincent Shih metaphor als Bezeichnung sowohl für die Metapher als auch für das Simile verwendet (LIU-SHIH 1959 [520]: 195, Anm. 1), muss wohl als der Übersetzungstechnik geschuldete Unschärfe akzeptiert werden.

132 In der obigen Aufzählung entspricht meine deutsche Übersetzung Toda Kōgyōs Japonisierung in SSKT 65. Vincent Shih übersetzt „Abbilden“ (xie 写) mit description und to signify, „Idee beigeben“ (fu yi 附意) mit to stand for ideas, ,zum Sachverhalt passen“ (qie shi 切事) mit to intimate the nature of certain facts, „das Wort erheben“ (yang yan 遗言) mit to use figures of speach, „Beispiele geben“ ( $y u$ 喻 und $p i$ 譬) mit to stand for, ,,von gleicher Art sein“ (lei 類, rui su) mit to signify, ,,imitieren“ (ni 擬, gi su) mit to symbolize, „vergleichen“ (fang 方, kurabu) mit to use as a figure for und „zum Abbild passen“ (qie xiang 切象) mit to illustrate. Damit macht Shih zumindest stilistisch auf die Differenziertheit des Originals aufmerksam. Dem Original am nächsten kommt freilich die Japonisierung Todas, während Li Zhaochu in seiner deutschen Übersetzung die differenzierte Schreibung des Originals durch die einheitliche Übersetzung aller genannten Formulierungen mit „vergleichen“ (LIU-Li 2007 [520]: 192) vollkommen nivelliert und den Text damit entstellt.

133 Freilich meint Liu mit bi 比 gleichzeitig den Vergleich, wie zwei der oben zitierten Passage folgenden Beispiele (Your hemp robe is like snow und The two outside horses go as if they were dancing; LIU-SHIH 1959 [520]: 196; Unterstreichungen nicht im Original) zeigen. 
physischen und physischen Begriffen der Philosophie operiert, und weil das Santi shi andererseits einen enormen Einfluss auf die japanische Dichtungstheorie ausübte. Die ursprünglich Tang xian santi shi fa 唐賢三体詩法 ([Regeln der Dichtung in dreierlei Gestalt von Weisen der Tang-Zeit]), später kurz Santi shi betitelte Anthologie wurde etwa 1250 von Zhou Bi 周芣 (fl. 1250) zu didaktischen Zwecken kompiliert und enthält 494 Gedichte von 167 Dichtern. „Dreierlei Gestalt“ meint die drei Versmaße qiyan jueju 七言絶句 (auf vier siebenfüßige Verse abgekürztes Gedicht), qiyan lüshi 七言律詩 (vier siebenfüßige Verse mit geregelten Ton- und Reimabfolgen) und wuyan lüshi 五言律詩 (vier fünffüßige Verse mit geregelten Ton- und Reimabfolgen). Die japanische Rezeption einer von Shi Yuanzhi 釋圓至 (1256-1298) und seinem Zeitgenossen Pei Yu 裴廋 (Lebensdaten unbekannt) kommentierten Version dieses Textes begann mit einer Vorlesung des soeben vom Studium in China zurückgekehrten Rinzai-Mönchs Chūgan Engetsu 中簄円月 (13001375). ${ }^{134}$ Hiernach verbreitete sich unter dem sinojapanischen Titel Santai shi diese kommentierte Version in Japan, ausgehend von den fünf großen Klöstern Kyōtos und zunächst in japonisierter (wakoku 和刻) Form. Nicht zuletzt der politisch wie wissenschaftlich ungemein einflussreiche neokonfuzianische Gelehrte Hayashi Razan 林羅山 (1583-1657) verhalf mit seiner Kommentierung dem Text zu Bekanntheit und Akzeptanz, so dass ab dem Ende des 17. Jahrhunderts zahlreiche Japonisierungen, Übersetzungen ins Japanische und ausführliche Kommentierungen des Santi shi folgten und zu Stilmustern für die japanische kanshi-Dichtung avancierten. ${ }^{135}$ Die in der Edo-Zeit populärste Version des Santai shi ist das Zōchū Tōken zekku Santai shi hō 増註唐賢絶句三体詩法 (Versionen von 1669, 1685, 1696 und 1703). ${ }^{136}$ Daneben gibt es aber zahlreiche weitere Bearbeitungen und Auszüge. ${ }^{137}$ Von besonderer Bedeutung für die japanische Literaturtheorie ist das Wakun Santai shi 和訓三体詩 ([Japonisiertes und erläutertes Santi shi], 1714), eine vom Bashō-Schüler Morikawa Kyoroku 森川許六 (1656-1715) geschaffene kom-

134 HAYAKAWA 1969.

135 HAYAKAWA 1969.

1361685 im Verlag Eikodō 永古堂, 1685 auch im Verlag Kikōdō 既康堂, 1669 und 1696 im Verlag Tsutsuiya Rokubē 筒井屋六兵衛), 1703 im Verlag Kikōdō 既康堂.

137 Um nur einige wenige zu nennen: 1682: Kaisei Santai shi 改正式體詩 (Subkommentare: Hayashi Razan) im Verlag Tsutsuiya Rokubē; 1685: Jūkōsei Santai shi 重挍正三體詩 im Verlag Teishōken 禎照軒; 1692: Kōsei Santai shi 挍正三體詩 (Subkommentare: Hayashi Razan) im Verlag Eishōken 英松軒; 1694: Santai shi 三體詩 (Subkommentare von Sera Ryūan 世良柳安) im Verlag Itō Gorōbē 伊藤五郎兵衛. Endgültig in breiten gebildeten Gesellschaftsschichten angekommen ist die kanshi-Anthologie durch die 1823 im sonst auf gehobene Unterhaltungsliteratur spezialisierten Verlag Kawachiya Mohē 河内屋茂兵衛 produzierte Version des Titels Tō Santai shi chū 唐三體詩註 ([Die Tang-zeitlichen Gedichte dreierlei Gestalt mit Kommentaren]). 
mentierte Japonisierung des ersten, die Versform der qiyan jueju 七言絶句 behandelnden Abschnittes, durch welche die ästhetische Theorie der kanshi-Dichtung Eingang in die Haikai-Theorie im Umfeld des Matsuo Bashō fand. ${ }^{138}$ Bemerkenswert ist weiterhin die folgende These aus Kyorokus Vorwort.

Bezüglich Gedichten, bezüglich Texten. Ein Gedicht ist ein Bild, welches das Herz abbildet. Der [Prosa-]Text ist ein Bote, welcher einen Zweck darlegt. Menschen, welche kein Verständnis für Bilder haben, sind auch Gedichten und Texten fern. In den alten Zeiten gab es keinen Poeten oder [Prosa-]Autor, welcher sich nicht auf Bilder verstand. Wang Wei und Dongpo sind [Beispiele]. ${ }^{139}$

Konsistent ist hier die Unterscheidung der Gegenstände von Lyrik („Gedichte“, shi 詩) und Prosa („Text“, bun 文): Gegenstand der Lyrik ist demnach die Emotion, Gegenstand der Prosa der Sachverhalt. Nachvollziehbar ist es auch, für das Verständnis der als Bild des Herzens begriffenen Lyrik ein Verständnis für Bildkunst vorauszusetzen. Nicht nachvollziehbar scheint dagegen die Beziehung der Prosa zur abbildenden Kunst: Prosa bildet bei Kyoroku nicht ab, und doch setzt er einen Sinn für die Bildkunst für deren Verstehen voraus.

Die Popularität des Santai shi hielt in Japan auch nach der vielbeschworenen „Zeitenwende“ der Meiji-Restauration (1868) ungebrochen an, was sich nicht zuletzt am Erscheinen einer umfangreich kommentierten Version des Dichters und Sinologen Ishikawa Kōsai 石川鴻斎 (1833-1914) in den Jahren 1883 bis 1885 zeigt. Selbst von Mori Ōgai und Natsume Sōseki 夏目漱石 (1867-1919), zwei Leitfiguren der Modernisierung der japanischen Literatur in der Aufklärungsperiode, wurde die über 600 Jahre alte Anthologie intensiv rezipiert. Wir haben es also mit einem Text zu tun, welcher die japanische Rezeption chinesischer Literatur sowie die japanische Literaturtheorie nachhaltig prägte.

138 Murakami Tetsumi entwickelt aus Kyorokus kommentierten Übersetzungen der 74 chinesischen Originalgedichte die folgenden groben Modelle: (a) eng an das Originalgedicht angelehnte, wörtliche Übersetzung; (b) phantasievolle, mit gestalterischen Zusätzen ausgestattete Übertragungen; (c) Deckung mit persönlichen Erfahrungen (MURAKAMI 1994: 171-172). Den jüngsten kommentierten modernen Nachdruck des Santi shi in japanischer Bearbeitung bietet MURAKAMI 1978 (Asahi shinbun; Chūgoku koten sen 29-32).

139 Shi ya, bun ya. Shi wa kokoro wo utsusu no e nari. Bun wa shoyō wo benzuru no tsukai nari. E ni tsū sezaru hito wa shibun ni utoshi. Inishie no shijin bunjin e wo yoku sezaru hito nashi. Ō I, Tōha kore nari. 詩也。文也。詩は心をうつすの絵也。文は所用を弁ずるのつかひ也。絵に通せざる 人は詩文に疎し。いにしへの詩人文人画を能せざる人なし。王維、東坡これなり。(FUJII 2015: 13; MoRIKAWA 1899 [1714]: 1 weicht von FuJI 2015 im Schriftgebrauch geringfügig ab). „Wang Wei“ und „Dongpo“: die chinesischen Dichter Wang Wei 王維 (699-761) und Su Dongpo 蘇東坡 (10371101). Die Vorstellung von einem Gedicht als Bild finden wir auch in der Literaturtheorie Tansō shiwa ([Tansōs Gespräche über die Poesie], 1883 [1856]) des Hirose Tansō (S. 163). 
Innerhalb der Aufteilung der Sammlung in die oben erwähnten „Drei Gestalten“ unterscheidet der Kompilator Bo Jiang 伯弜 (Schriftstellername des Zhou Bi 周怩, fl. 1250) zwischen shi 実 („Fülle“, jap. jitsu) und xu 虚 („Leere“, jap. kyo). $\mathrm{Zu}$ dieser Einteilung geben die Kommentatoren Shi Yuanzhi und Pei Yu für den Begriff shijie 実接 („Anschluss der Fülle“, jap. jissetsu) folgende Erläuterungen:

Bo Jiang sprach: Was die Regeln des Umbruchsverses angeht, so halte ich im großen und ganzen den dritten Vers für die Hauptsache. Darin, wie es von Anfang bis Ende geradewegs durchgeht und keinerlei Abschweifung enthält, liegt der Grund, weswegen [Dichtungen] anderer Epochen die der Tang nicht erreichen. Die Regel besteht nicht nur darin, dass man [im dritten Vers] einstweilen von einer Weiterführung abweicht, auch können die Menschen daran klar erkennen, dass die vollen Dinge den Gedanken verkörpern. Beim Anschlusse liegt im Wechsel die Kraft. ${ }^{140}$

Kyoroku kommentiert dies in seiner japonisierten Version des Santi shi wie folgt.

Fülle nennt man Dinge, welche eine Form haben. Leere nennt man, was im Herzen ist. Das liegt daran, dass sie keine Form haben. Das Anschließen nennt man das Zusammentreffen oder das Fortführen. Wenn die Verse 1, 2 und 4 leer sind, Vers 3 aber voll, so spricht man vom Stile des Anschlusses der Fülle. ${ }^{141}$

Damit übernimmt Kyoroku von den chinesischen Kommentatoren das Wort shi 実 (jap. jitsu) zur Bezeichnung der gegenständlichen (,vollen“) Welt, verwendet aber statt des von den chinesischen Kommentatoren zur Bezeichnung der nicht gegenständlichen, vorgestellten Welt verwendeten Wortes yi 意 („Sinn“, jap. $i$ ) das Wort kyo 虚 („Leere“). Aus seiner ausführlichen Erläuterung wird klar, dass „Sinn“ und „Leere“ hier als synonyme Begriffe zu sehen sind. Die Trennung von „Fülle“ und „Leere“ („Sinn“) nach einzelnen Versen des Gedichtes unterstreicht zum einen deren Kontrast, zum anderen die favorisierte Funktion und Funktionsweise der Poesie. Ob die von den chinesischen Kommentatoren und Kyoroku postulierte Trennung der beiden Sphären in der Produktion der Tang-Poesie konsequent umgesetzt wurde, ist unerheblich. Erheblich ist dagegen der anzunehmende Einfluss der Theorie auf die Rezeption der in Japan intensiv wahrgenommenen Anthologie

140 Haku Kyō iwaku, zekku no hō wa, taitei dai sanku wo motte shu to su. Shubi sotchoku shite enkyoku naki mono kore iji no Tō ni oyobazaru yuen nari. Sono hō wa tada hisashiku sono den wo shissuru nomi ni arazu, hito mo mata kore wo motte jitsuji $i$ wo gū suru wo yoku akiraka ni shiru. Shikōshite sessuru toki wa tenkan chikara ari. 伯弜曰絶句之法大抵以第三句為主首尾率 直而無婉曲者此異時所以不及唐也其法非惟久失其伝人亦鮮能知之以実事寓意而接則転換有力 (ZHOU-MATSUNAGA 1653-I: 1a; ZHoU-HAYASHI 1718-I: 17a).

141 Jitsu wa katachi aru mono wo iu. Kyo wa shinjō wo iu. Katachi naki yue nari. Setsu wa kai nari, mata wa zoku nari. Ichi ni yon no ku kyo ni shite, san no ku jitsu naru wo iu. Kore wo jissetsu no tai to iu. 実は形ある物を云ふ、虚は心上を云ふ、形なき故なり、接は会なり、又は続なり、一二 四の句虚にして、三の句実なるを云ふ、是を実接の体と云ふ。 (KYOROKU-KIMURA 1899 [1714]: 1). 
und die sich daraus für die Literaten ergebenden normativen Ansprüche an sowie die Wertvorstellungen von deren Produktion.

Der überwiegende Teil der nachstehenden Metatexte bewegt sich im Rahmen der oben aufgeführten prototypischen Beispiele.

\subsection{Realisierungen der „philosophischen“ Muster der Dichotomie „Leere und Fülle“ in Literaturtheorien der Jahre 914-1850}

Die für die vorigen Abschnitte aus philosophischen Quellen extrapolierten Muster wurden in Varianten zwischen den Jahren 914 bis 1850 in konkreten Literaturtheorien realisiert. Selbst wenn die „philosophischen“ Muster den Theoretikern unseres Betrachtungszeitraums nicht bekannt oder bewusst waren, dürfen die im Folgenden beispielhaft genannten literaturtheoretischen Realisierungen der Muster dann als bekannt vermerkt werden, wenn zitathafte Bezüge auf sie verweisen. Dass die Muster freilich niemals als ein geschlossenes, synchrones System und über die Grenzen von Regionen und Schulen hinweg funktionierten, muss vorausgesetzt werden. Denn zwar sind wenigstens für die Edo-Zeit (etwa 1600-1868) jene Formen wissenschaftlicher Kommunikation nachgewiesen, welche dies vorstellbar machen. ${ }^{142}$ Aber die Fachliteratur zu Lesezirkeln und Diskussionskreisen der EdoZeit liefert keinen Anhaltspunkt dafür, dass über Grenzen der Region oder Schulen hinausgehende Diskurse sich auch auf theoretische Diskussionen der Wortkunst erstreckt haben könnten. Wie eingangs erklärt, müssen wir uns damit begnügen, eine Übersicht thematischer Schwerpunkte der auf die Dichotomie „Fiktion - Wirklichkeit“ bezogenen Literaturtheorien zu erreichen. Zwar besetzen viele der als Mustervorrat analysierten Literaturtheorien der Jahre 914 bis 1850 mehrere der im folgenden getrennt gehaltenen Themen, aber der Übersichtlichkeit halber verzichte ich auf eine Darlegung ihrer Nebenthemen. In der Praxis der japanischen Literaturtheorie haben wir es mit einem Repertoire von Möglichkeiten und mehr-

142 Insbesondere MAEDA 2012, Үокота 2015 und OKAMURA 2017 können in detaillierten Analysen der für Lesezirkel geltenden Verhaltensregeln, Veranstaltungsabläufe sowie durch Analysen von Berichten aus Lesezirkeln und den regen Leihverkehr unter wissenschaftlichen Privatbibliotheken plastisch darlegen, wie lebendig und regionenübergreifend schon seit Itō Jinsai und Ogyū Sorai Lektüre- und Debattierzirkel in der geistigen Auseinandersetzung mit wissenschaftlicher Literatur zu ethischen und staatspolitischen Fragen sowie zur materiellen Kultur in der Edo-Zeit waren. 
deutigen Zuordnungen zu tun, vor dessen Hintergrund die nachstehende Übersicht nur als vereinfachende Orientierungshilfe akzeptiert werden kann.

In der nachfolgenden Abbildung 4 steht „Fiktion“ für den literarischen Text im Sinne der Abbildung 2 (S. 56), „Wirklichkeit“ für die Bestandteile der außerliterarischen Welt. Die unterhalb der Dichotomie „Fiktion - Wirklichkeit“ genannten Bestandteile der außerliterarischen Welt werden in den analysierten Literaturtheorien entweder als Signifikant oder als Signifikat des literarischen Textes thematisiert. Mitzudenken sind bei der Abbildung als „Weltbestandteile“ jeweils auch weitere Protagonisten (zu „Wahrheit“ auch „Wahrhaftigkeit“, „Erkenntnis“, „Gesetzmäßigkeit“ etc.) sowie deren Antagonisten (zu „Wahrheit“ auch „Unwahrheit“, „Lüge“ etc.).

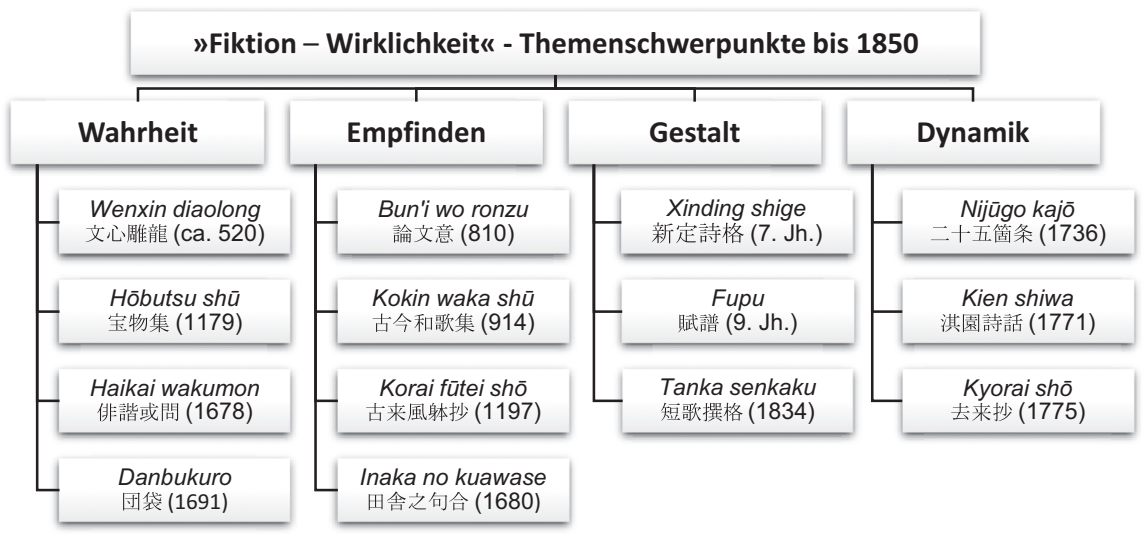

Abbildung 4: „Fiktion - Wirklichkeit“: Themenschwerpunkte der Literaturtheorie bis 1850.

Die in Kursive gegebenen Kurztitel verweisen auf Textbeispiele aus der Gruppe „Primärquellen“, deren exemplarische Vielfalt ich im folgenden Abschnitt darlegen will - das bereits in Abschnitt 3.3.1 behandelte Wenxin diaolong ausgenommen. Dass bei der obigen Beispielauswahl der Zeitraum 1776 bis 1850 mit nur einem Text vertreten ist, hängt mit dem epigonalen Charakter der Literaturtheorien dieser Zeit zusammen: Vielfach werden Theoreme des vor 1776 liegenden Zeitraums wiederholt oder verwässert wiedergegeben. Einem Grund für die Epigonalität kann hier der Stringenz halber nicht weiter nachgegangen werden, doch liegt die Vermutung nahe, dass die ab der Mitte des 18. Jahrhunderts vorherrschende Kommerzialisierung der Literatur (MAY 1983) mit ihren homogenisierenden Marktmechanismen auch die Literaturtheorie beeinflusst hat. 


\subsubsection{Wahrheit‘ in japanischen Literaturtheorien}

„Wahrheit“ steht hier stellvertretend für die in KRACHT 1986 am Beispiel des Denkens des Yamagata Bantō umrissene Begriffswelt. ${ }^{143}$ Diese umfasst Vorstellungen von Faktizität und sachlicher wie ethisch-moralischer Konformität sowie deren jeweilige Antagonisten. In dieser Begriffswelt werden das sachlich nicht Verifizierte und der Irrtum von der ethisch zu verdammenden „Lüge“ nicht getrennt. Literaturtheorien dieser Kategorie verwenden häufig Wörter wie makoto 真 (,Aufrichtigkeit“), michi 道 (auch $d \bar{o}$, „,[der rechte] Weg“), ri 理 (,[Ur-]Prinzip“) sowie Antonyme wie bōtan 妄誕 (,verwirrende Unwahrheiten“), itsuwari 偽り und uso 嘘 („Lügen“) sowie jitsu 実 (,Wirklichkeit“). In KRACHT 1986 hierzu ausführlich:

„Sprachlich drückt sich diese Verteidigung eines spezifisch gedachten Wirklichkeitsverständnisses in binären Oppositionen nach dem Muster 'Lüge-Wahrheit', 'Traum-Wirklichkeit' aus, so dass auf der einen Seite „irrige Worte“ (byūgo), „leere Worte“ (kyogen, kyogo), „leere Erklärungen“ (kyosetsu), „leere Lügen“ (kyotan), „leere Schriften“ (kyosho), „leere Dinge“ (kyobutsu), „leere Abhandlungen“ (kūron), „leere Reden“ (kyodan), „lügenhafte Erklärungen“ (bōsetsu), „lügenhafte Reden“ (mōdan), „lügenhafte Worte“ (bōgen), „Lügen“ (bōtan, itsuwari, mō, fumō u. a.), „Fälschungen“ (gisaku), „Nachahmungen“ (nisemono), „Konstrukte“ (koshiraegoto, koshiraemono), „Allegorien“ (gūgen), Dinge „ohne Beweisgrund“ (shōko aru koto nashi) usw. stehen und auf der anderen Seite ein Vokabular der Wirklichkeitsorientierung, dessen Gebrauch am plausibelsten die Richtigkeit, Angemessenheit, Wahrheit eines Gedankens, ggf. durch die Hinzufügung des modalen „wirklich“ (jitsu ni, jitsu no, jitsu wa), unterstreicht. So ist die Rede von der „wirklichen Begebenheit“ (jiiitsu) und der akademischen Hinwendung zur Wirklichkeit, dem „wirklichkeitsbezogenen Studium“ (jitsugaku), dem außerhalb der Gelehrsamkeit „,wirklichkeitsbezogenes Handeln“ (jikkō) entspricht, das mit den „wirklichen Dingen“ (jitsubutsu) zu tun hat. In der Sprache der Erkenntnis hat „verläßliche Wirklichkeit“ (kakujitsu) und „treffende Wirklichkeit“ (tekijitsu), was durch den „wirklichen Beweis“ (jisshō), die „Wirklichkeit der [Präzedenz]fälle“ (kojitsu) oder besser die „wirklichen Spuren“ (jisseki) des gegenwärtigen Augenscheins, d. h. durch „wirkliche Anschauung“ (jikken), bzw. durch hinter den Worten des Kanons sich verbergende, „wirkliche Regeln“ (jïpō) als „wahr und wirklich“ (shinjitsu) bestätigt bzw. in seiner „wirklichen Bedeutung“ (jitsugi) erkannt werden kann und damit den Status „gesicherter Ausführungen“ (kakuron), „,gesicherter Erklärungen“ (kakusetsu) gewinnt. In der Sprache der Ethik werden die zentralen Werte der „Wahrhaftigkeit“ (sei), „Loyalität“ (chū) und „Achtung“ (kei) wie auch der „Weisheit“ (chi) emphatisch verstärkt und, wenigstens dem Anspruch des Wortes nach, der Innerlichkeit enthoben, indem von ihnen als „wahrhaftig und wirklich“ (seijitsu), „loyal und wirklich“ (chūjitsu) als zwei Formen der Aufrichtigkeit gesprochen wird oder auch von der „Wirklichkeit der Wahrhaftigkeit und Achtung“ (seikei no jitsu) und der „wirklichen Weisheit“ (jitchi). Hinter diesen Forderungen steht als Persönlichkeitsideal der „wirkliche Mensch“ (jitsu no ningen) [...].“144

143 Siehe Fussnote 118.

144 KRACHT 1986: 283, Anmerkung 229. 


\subsubsection{Wahr ist nur die empirisch nachprüfbare Wirklichkeit: das Hōbutsu shü (1179) des Taira no Yasuyori}

Das von Taira no Yasuyori 平康頼 (1146-1220) kompilierte Hōbutsu shū 宝物集 (A Collection of Treasures, 1179), eine Sammlung buddhistischer Predigterzählungen (setsuwa), enthält in Band 5 eine Predigt über die Fünf Verbote (gokai), namentlich (1) nicht zu töten, (2) nicht zu stehlen, (3) keine Unzucht zu treiben, (4) keine berauschenden Getränke zu sich zu nehmen und (5) keine haltlosen Worte (mōgo 妄語) zu sprechen. Was dabei unter „haltlosen Worten“ zu verstehen sei, erläutert der folgende Passus.

Zum fünften [Verbot]: ,Keine haltlosen Worte sprechen' meint, keinerlei leeren Worte [soragoto 虚語] zu sprechen, also [nicht] zu sagen, dass man das Gesehene nicht gesehen habe, das nicht Gesehene gesehen habe. ${ }^{145}$

Selbst wenn man unterstellt, dass in dieser Definition mit „sehen“ (miru) nicht allein die optische Wahrnehmung der physischen, sondern auch die kognitive Wahrnehmung der metaphysischen Welt gemeint sei, bleibt der enthaltene Wahrheitsbegriff reduziert auf vorgefundene Sachverhalte (koto 事) und schließt die sprachliche Schaffung von nicht faktenbasierten Sachverhalten grundsätzlich aus. Zwischen „haltlosen Worten“ und der „Wahrheit“ besteht hier eine streng antonymische Beziehung. Auf die oben zitierte Passage folgen Schilderungen drastischer Strafen für das eigenmächtige Schaffen von Neuem, von denen im Zusammenhang mit fiktionaler Literatur die folgende von Interesse ist.

In jüngerer Zeit fiel Murasaki Shikibu in die Hölle, weil sie das Genji monogatari mit leeren Worten verfasst hatte, und weil ihr Leiden [dort] so unerträglich war und sie darob in den Träumen der Menschen erschien, versammelten sich Lieddichter und verfassten an einem Tage Sutren [ab], um ihre Seele zu beruhigen; man möge sich daran erinnern. ${ }^{146}$

Diese Passage ist zum locus classicus der moralischen Verdammung fiktionaler Literatur geworden - Legionen von Metatexten folgen dem hier gegebenen Mus-

145 Fumōgo to mōsu wa, mitaru koto wo mizu to ii, mizaru koto wo mitaru to ii, subete soragoto wo senu wo mōshitaru nari. 不妄語と申すは、見たる事を見ずといひ、見ざる事を見たるとい ひ、すべて虚言をせぬと申したる也。(SNKBT 40: 225).

146 Chikaku wa, Murasaki Shikibu ga soragoto wo motte Genji monogatari wo tsukuritaru tsumi ni yorite, jigoku ni ochite kugen shinobigataki yoshi, hito no yume ni mietari keri to te, utayomidomo no yoriaite, ichinichi kyō kakite, kuyō shikeru wa, oboe tamau ran mono wo. ちかくは、紫 式部が虚言をもつて源氏物語をつくりたる罪によりて、地獄におちて苦患しのびがたきよ し、人の夢にみえたりけりとて、歌よみどものよりあひて、一日経かきて、供養しけるは、 おぼえ給ふらんものを。(SNKBT 40: 229). 
ter. $^{147}$ Es ist dabei durchaus bemerkenswert, dass die Verdammung einen Prosatext traf und nicht die Lyrik. Die bijektive Verbindung von Prosa und an Fakten orientierter Wissenschaft erweist sich in der Literaturgeschichte so lange als stabil, wie sich Erzählprosa nicht als Teilfeld eines distinktiven Feldes „Kunst“ emanzipiert hat.

\subsubsection{2 „Leere“ ist Lüge, „Fülle“ ist Wahrheit: Okanishi Ichūs Haikai wakumon (1678) und der chinesische Philosoph Zhuang Zhou}

Okanishi Ichū 岡西惟中 (1639-1711), Schüler des Haikai-Dichters Nishiyama Sōin 西山宗因 (1605-1682) und prominenter Vertreter der von Sōin gegründeten Danrin 談林-Schule, trat vor allem durch zwei herausragende Schriften der Haikai-Theorie in Erscheinung: das Haikai mōgyū 俳諧蒙求 ([Das Mengqiu der Haikai], ${ }^{148}$ 1675) und das Haikai wakumon 俳諧或問 ([Fragen zum Haikai], 1678). ${ }^{149}$ Das Haikai mōgyū ist die erste Haikai-Theorie, die in der Metaphorik (gūgen 寓言) des Zhuangzi das ästhetische Ideal der Hakai-Dichtung sieht. Im Haikai wakumon arbeitet Ichū unter Bezug darauf in 17 Paragrafen die Lehrmeinung der DanrinSchule heraus. Die enge zeitliche Abfolge ihrer Veröffentlichung sowie inhaltliche Deckungen rechtfertigen es, das Haikai mōgyū und das Haikai wakumon im Folgenden als eine inhaltliche Einheit zu behandeln. Metaphorik (gūgen) als technischen Begriff definiert Ichū im Haikai wakumon wie folgt:

„Metapher“ bedeutet, etwas, das man im Herzen empfindet, sprachlich zu äußern, indem man es mit Dingen gleichsetzt oder in ein Geschehen kleidet. ${ }^{150}$ Was das Herz im Zhuangzi betrifft, so existierte das dao noch vor dem Urprinzip des Universums, weswegen Himmel, Erde, Menschen, Dinge, das Beseelte und das Unbeseelte eins sind und [dem dao]

147 Details bei BALMES 2015.

148 Das chinesische Mengqiu 蒙求 ist ein von Li Han 李瀚 (fl. 746) erstelltes, enzyklopädisch angelegtes Lehrbuch für Kinder. Davon abgeleitet bedeutet Mengqiu (jap. Mōgyū) als Titelbestandteil in etwa „Erste Anleitung“.

149 Yonetani Iwao 米谷嚴 begründet seine Annahme, dass Shūchikudō ein Pseudonym Ichūs ist, mit der fast vollständigen Identität von Rhetorik und Inhalt zwischen dem Haikai wakumon und Schriften Ichūs (NKBD, s.v. Haikai wakumon).

150 Diese Definition unterscheidet sich nur wenig von dem, was im Vorwort des Kokinshu (Abschn. 3.4.2.2) dazu gesagt wird: „Many things happen to the people of this world, and all they think and feel is given expression in things they see and hear" (KI-RodD-HENKENIUS 1996 [914]: 36). Original: Yo no naka ni aru hito, kotowaza shigeki mono nareba, kokoro ni omou koto wo, miru mono, kiku moni ni tsukete, iidaseru nari. 世中にある人、ことわざしげ きものなれば、心におもふことを、見るもの、きくものにつけて、いひいだせるなり。 (NKBT 8: 93). 
nicht entrinnen. Die Dingwelt und das Ich haben im Grunde dieselbe Wurzel, weswegen man nicht dies als gutartig, jenes als bösartig bezeichnen kann. Dieses dao hat weder einen Ton noch einen Geruch, und auch eine bestimmte Gestalt ist ihm nicht eigen. ${ }^{151}$

Welche Inhalte nun durch die Verbindung von „Leere“ und „Fülle“ idealerweise in einem Haikai verarbeitet werden sollen, erläutert Ichū im Haikai mōgyū, indem er zunächst anhand ausführlicher Zitate aus Kapitel 1 (Xiaoyao you 逍遥遊, „Free and easy wandering“) des Zhuangzi illustriert, wie dort das Gigantische klein, das Ewige zu einem kurzen Moment, der kurze Moment zu einer Ewigkeit gemacht, überhaupt alle Dimensionen in ihr Gegenteil verkehrt und damit relativiert werden. ${ }^{152}$ An diese Illustration schließt sich die folgende Quintessenz an.

Die metaphorischen Worte des Zhuangzi bringen die Maße durcheinander, vertauschen langes Leben und frühes Sterben, machen das Leere zur Fülle, die Fülle zur Leere, das Seiende zu Nichtseiendem und das Nichtseiende zu Seiendem, aber das sind sie nicht allein: Sie sind ganz genau das, was das Haikai zu einem Haikai macht. ${ }^{153}$

Zhuang Zhou selbst rechtfertigt seinen häufigen Einsatz von Metaphern in Kapitel 27 (Yuyan 寓言, „Metaphern“) des Zhuangzi mit dem pragmatisch-didaktischen Argument, dass sie seine Philosophie verständlicher machten: Metaphorik

151 Gügen to wa, wa ga kokoro ni omou koto wo, mono ni hi shi koto ni taku shite iidasu gi nari. Somosomo Sōji ga kokoro wa, dō wa taikyoku no mae ni areba ten, chi, jin, butsu, yūjō, hijō hitotsu shite, kore ni moruru koto nashi. Butsuga moto dōkon nareba, kare wo zen to shite kore wo aku to subekarazu. Kono michi wa oto mo naku ka mo naku, sashite iu beki katachi mo nashi. 寓 言とは、我心に思ふ事を、物に比し事に託して云ひ出す義也。抑も荘子が心は、道は太極の 前にあれば天、地、人、物、有情、非情ひとつとして、爰にもるっことなし。物我素同根な れば、彼を善とし是を悪とすべからず。この道は音もなく臭もなく、さしていふべき形もな し。(OKANISHI-SASSA 1914 [1678]: 4).

152 Zhuang Zhou gibt als Größe des (in Wirklichkeit nicht einmal $1 \mathrm{~cm}$ großen) Fischrogens (chin. kun 鯤) mehrere tausend li (1 li $\approx 1$ Meile) an. Der Rogen verwandelt sich in den mythischen Phönix-Vogel (chin. peng 鵬), der ebenfalls mehrere tausend li misst. Originaltext: 北冥 有魚、其名為鯤。鯤之大、不知其幾千裡也。化而為鳥、其名為鵬。鵬之背、不知其幾千裡 也。(Zhuangzi zhu 莊子注 1: 1a, SKQS-Edition). „In the Northern Darkness there is a fish and his name is K'un. The K'un is so huge I don't know how many thousand li he measures. He changes and becomes a bird whose name is P'eng. The back of the P'eng measures I don't know how many thousand li across [...]“" (ZhuANG-WATSON 1968 [130 v. Chr.]: 29-35).

153 Kore, ka no taishō wo midari, juyō wo tagae, kyo wo jitsu ni shi, jitsu wo kyo ni shi, ze naru wo hi to shi, hi naru wo ze to suru Sōji ga gūgen, kore nomi ni kagirazu, mattaku Haikai no Haikai taru nari. 是、かの大小をみだり、寿夭をたがへ、虚を実にし、実を虚にし、是なるを非とし、非 なるを是とする荘子が寓言、これのみにかぎらず、全く俳諧の俳諧たるなり。(OKANISHI-IIDA 1972 [1675]: 83). 
als bequemer Umweg statt des unbequemen, direkten Weges zum selben Inhalt. ${ }^{154}$ Ichū sieht nun in der Haikai-Dichtung nicht einen bequemen Umweg, sondern den bequemen direkten Weg - die lyrische Demonstration der Einheit allen Seins, die er wie schon Zhuang Zhou im Entstehen aus ein und demselben Urprinzip begründet. Von dieser idealen Einheit entfernt sieht er allerdings manche Dichtungen seiner Gegenwart, denen seiner Ansicht nach die Balance von „Leere“ und „Fülle“ fehlt.

\begin{abstract}
Was die Dichtungen der jüngsten Zeit angeht, legen sie in ihren Worten die Logik, ob sie nun zutrifft oder nicht, so zurecht, dass aus einem Papierkleide ein Brokatumhang wird; ist das eine zu stark, ist das andere zu schön, man empfindet keine Spannung darin, auch machen sie Tatsachen zu Gelogenem, Gelogenes zu Tatsachen, und es scheint, dass man dies als den Wesenskern des Haikai angenommen hat. ${ }^{155}$
\end{abstract}

Die Verbindung von „Papierkleid“ (kamiko) und „Brokat“ (nishiki) steht hier nicht für einen Qualitätsunterschied, sondern für die nur lockere Verbindung zweier wesensfremder Dinge, die wegen ihrer großen Entfernung in der Kürze des Haikai nicht zu einer auf ihrem gemeinsamen Ursprung gründenden Synthese gebracht werden können. Solche Kontraste sieht Ichū im Haikai wakumon als die Verbindung nicht von „Leere“ und „Fülle“, sondern von Wahrheit (jitsu) und Lüge (itsuwari).

\title{
3.4.1.3 Unwahr ist nicht gleich gelogen!: Das Danbukuro (1691) des Hōjō Dansui
}

Das Danbukuro 団袋 ([Dansuis Beutel], 1691) ist eine vom Saikaku-Schüler Hōjō Dansui 北条団水 (1663-1711) erstellte Sammlung von Gedichten und Aussprüchen zur Haikai-Dichtung. Die Sammlung enthält unter anderem je eine von Dansui

154 „These imputed words which make up nine tenths of it are like persons brought in from outside for the purpose of exposition. A father does not act as go-between for his own son, because the praises of the father would not be as effective as the praises of an outsider" (ZHUANG-WATSON 1968: 303). Original: 寓言十九、藉外論之。親父不為其子媒、親父譽之、不 若非其父者也。(Kapitel 27, Yuyan 寓言) (Zhuangzi zhu 莊子注 9: 8b-9a, SKQS-Edition).

155 Kono goro no ku domo wa, kamiko nareba nishiki nite zehi tomo ni kotowari wo tadashiku ii tsumete, arui wa tsuyo sugi, aru wa utsukushi sugi, kyō naku oboe sōroi, mata jitsu wo itsuwari ni shi, itsuwari wo jitsu ni ii nasu wa, Haikai no hon'i to uketamawari sōrō to mietari. 此の頃の 句どもは、紙子なれば錦にて是非ともに理を正しくいひつめて、或ひはつよ過ぎあるはうつ くし過ぎ、興なく覚へ候、また実を偽りにし、偽りを実にいひなすは、俳諧の本意と承り候 と見えたり。(OKANISHI-SASSA 1914 [1678]: 11). 
und Saikaku im Dezember 1690 zusammengestellte Sammlung von Gedichten und Kommentaren sowie eine von Dansui und Ikenishi Gensui 池西言水 (16501722), Nakao Gakoku 中尾我黒 (1640-1710) und Itō Shinkoku 伊藤信徳 (16321698) nach Jahreszeiten geordnete Haikai-Sammlung. Enthalten ist unter dem Titel Haikai ichigen hōdan 俳諧一言芳談 („Berühmte Sentenzen zur HaikaiDichtung“) auch eine Sammlung teils literaturtheoretischer Aussprüche verschiedener Haikai-Dichter. Darin zitiert Dansui seinen Lehrer Ihara Saikaku 井 原西鶴 (1642-1693), später vor allem für seine das bürgerliche Milieu schildernde Erzählprosa des Genres ukiyozōshi bekannt, mit folgender These.

Saikaku spricht: ,Metaphorische Worte und Lügen sind doch etwas Verschiedenes! Eine erfinderische Geschicklichkeit sollte man doch nicht etwas Gemachtes nennen!“‘156

Die hier zitierte Unterscheidung könnte den argumentativen Kern der stereotyp defensiven Abgrenzung der Fiktionalität gegen Lüge bilden, wie wir sie eingangs der Abhandlung in den beiden Texten der Gruppe A kennengelernt haben.

Schon die hiermit besprochenen drei Beispiele machen die inhaltliche Breite der Kategorie „Wahrheit“ deutlich. Sie reicht von positivistischen bis zu ethischen Vorstellungen und Bewertungen des fiktiven Textes, und dies häufig in einer Literaturtheorie.

\subsection{2 ,Empfinden` in japanischen Literaturtheorien}

„Empfinden“ steht hier stellvertretend für die allgemein „Angerührtsein von den Dingen“ (mono no aware) apostrophierte Gemütsbewegung außerhalb des kognitiven Bereichs. Allerdings sind die Begriffswelten „Fühlen“ und „Denken“ wie im Deutschen auch im Japanischen nicht ganz voneinander zu trennen. Auch dass die meisten in diesem Areal der Literaturtheorie anzutreffenden Wörter in ihrer chinesischen Schreibung das Klassenzeichen „Herz“ (kokoro 心) enthalten, ändert daran nichts. Häufig verwendet werden hier nicht klar zu unterscheidende Wörter wie $i$ und kokoro 意 („Sinn“), shin und kokoro 心 („Herz“), jō und nasake 情 („Gefühl“) sowie shi und kokorozashi 志 („Neigung“). Die im Deutschen „Denken“ genannte, tendenziell kognitive Gemütsbewegung wird im vormodernen Japanischen mit den Wörtern kō 考 und kangau 考 bezeichnet. Interessanterweise kommen diese beiden

156 Original in Danbukuro (1691): Saikaku iu, gūgen to itsuwari to wa kotonaru zo, uso na takumi zo, tsukurigoto na mōsu zo. 西鵬云 寓言と偽と八異なるそうそなたくミそつくりことな 申そ (Hōjō-NOMA-YOSHIDA 1982-1983 [1691]: 138). 
Wörter, so weit zu sehen, in den einschlägigen Passagen japanischer Literaturtheorien zur Dichotomie „Fiktion - Wirklichkeit“ der Jahre 914 bis 1850 nicht vor.

\subsubsection{Der Sinn ist das Maß, die Stimme der Rhythmus der Dichtung: die Unzertrennlichkeit von Idee und Melodie im Bunkyō hifu ron (810-824)}

Das Bunkyō hifu ron 文鏡秘府論 (A Mirror on Literature and a Treasury of Marvels Treatise, 810-824) ${ }^{157}$ ist ein vom japanischen Shingon-Mönch Kūkai 空海 (774-835; postum Kōbō Daishi 弘法大師) verfasstes Vademecum der klassischen chinesischen Poesie und Prosodie. Er verarbeitet, nach thematischen Schwerpunkten untergliedert, vierzehn chinesische literaturtheoretische Texte, von denen nur drei außerhalb des Bunkyō hifu ron „überlebt“ haben. ${ }^{158}$ Kūkais Arbeit kann in ihrem Einfluss auf die frühe Literatur und Literaturtheorie Japans nicht überschätzt werden. Es überrascht nicht, dass das aus vierzehn Literaturtheorien zusammengestellte Kompendium Bunkyō hifu ron nicht ein einzelnes, synchron funktionierendes System darstellt, sondern derer mehrere, teilweise gar nicht miteinander zu vereinbarende.

Ein Passus aus dem Bunkyō hifu ron interessiert hier besonders: das Bun’i wo ronzu 論文意 ([Vom Sinn des Textes]) im Kapitel Nankan 南巻, ${ }^{159}$ denn es geht um die Grundsatzfrage der Dichtung im Allgemeinen.

[1] Im Allgemeinen ist zur äußeren Anlage der Dichtung zu sagen, dass der Sinn das Maß ist, die Stimme der Rhythmus. [2] Ist der Sinn hoch, so ist das Maß hoch, sind die Stimmen zu unterscheiden, so ist der Rhythmus rein. [3] Erst wenn Maß und Rhythmus vollständig sind, gibt es eine Melodie. [...] [4] Die Grundlage der Dichtung ist die Neigung. [5] Ist man im Herzen, so schafft man eine Neigung, äußert man sie in Worten, so schafft man Dichtung. [6] Das Gefühl bewegt sich im Inneren, doch Form nimmt es im Wort an, und erst dann schreibt man es auf das Papier. ${ }^{160}$

157 KŪKAI-Konishi 1953 [810-824]: 112; KōBō DAISHI 1910 [810-824]: 88. BodMAN 1988 bietet umfangreiche Teilübersetzungen und Analysen des Textes, nicht aber eine Übersetzung der oben zitierten Passage. Freilich wird der Gedanke der Kontrastierung von Gegenständlichem und Nichtgegenständlichem im Shige mehrfach aufgegriffen, wenn auch nicht jedesmal in Verbindung mit dem Terminus xushi.

158 Richard W. Bodman bietet eine kommentierte Liste der von Konishi Jin'ichi identifizierten Texte (BoDman 1988: 16-17).

159 Siehe S. 30.

160 [1] Oyoso sakushi no tei, i kore kaku nari, sei kore ritsu nari. [2] I takakereba sunawachi kaku takaku, sei wakimaereba sunawachi kaku kiyoshi. [3] Kaku ritsu mattō shi, shikaru nochi hajimete chō ari. [...] [4] Shihon shi nari. [5] Shin ni areba shi wo nashi, gen wo hassureba shi wo nasu. [5] Jō naka ni oite ugoki, shikōshite gen ni oite katachi wo nashi, shikaru nochi kami ni oite kore wo sho su nari. [1] 凡作詩之體、意是格、聲是律。[2] 意高則格高、聲辨則律清。 [3] 格律 
Der immaterielle Sinn ist demnach das Maß als Intention der Dichtung. Die Stimme steht hier pars pro toto für die Mittel der Materialisierung des Sinnes (der Intention) und gehört zur formenhaften Welt. Der Formenschatz gibt den Rhythmus vor. Erst wenn Intention und Form vollständig umgesetzt werden, hat die Dichtung eine Melodie. Ab Satz [4] formuliert der zweite Teil des Zitats im Prinzip dasselbe noch einmal mit anderen Worten. Schließlich stehen $i$ (Sinn), shin (Herz), shi (Neigung) und jō (Gefühl) zueinander wie Synonyme und verweisen auf die innere, formenlose Welt. Als solche stehen diese Begriffe der Form (katachi) und dem Wort (gen) in diesem Text als begriffliche Komplementärbegriffe gegenüber. Bemerkenswert ist nun, dass in dieser Passage mit der Materialisierung in Worten die Verwandlung des dynamischen Gegenstandes (der sich im Inneren bewegenden Neigung) in einen statischen Gegenstand einhergeht. Gleich ob es sich bei der Materialisierung um tatsächlich statische Substantive oder eigentlich dynamische Verben handelt, wird die eigentliche Dynamik im außersprachlichen Teil der Dichtung gesehen.

\subsubsection{Das Herz als Samen, die Worte der Dichtung als Blätter: das kana-Vorwort des Kokin waka shū (914)}

Als erste autochthon japanische Poetik gilt das kana-Vorwort der kaiserlichen Gedichtanthologie Kokin waka shū 古今和歌集 (A Collection of Poems Ancient and Modern, 914; künftig Kokinshū). Dort wird das Wesen der Poesie wie folgt beschrieben:

Japanese poetry has the human heart as seed and myriads of words as leaves. It comes into being when men use the seen and the heard to give voice to feelings aroused by the innumerable events in their lives. The song of the warbler among the blossoms, the voice of the frog dwelling in the water - these teach us that every living creature sings. It is song that moves heaven and earth without effort, stirs emotions in the invisible spirits and gods, brings harmony to the relations between men and women, and calms the hearts of fierce warriors. ${ }^{161}$

\footnotetext{
全、然後始有調。 [...] [4] 詩本志也。在心為志、發言為詩。 [5] 情動於中、而形於言、然後書 之於紙也。(KŪKAI-KonISHI 1953 [810-824]-I: 73).

161 KI-McCullough 1985 [914]: 3. Originaler Wortlaut: Yamato uta wa, hito no kokoro wo tane to shite, yorozu no koto no ha to zo narerikeru. Yo no naka ni aru hito, kotowaza shigeki mono nareba, kokoro ni omou koto wo, miru mono, kiku mono ni tsukete, iidaseru nari. Hana ni naku uguisu, mizu ni sumu kawazu no koe wo kikeba, iki to shi ikeru mono, izure ka uta wo yomazarikaru. Chikara wo mo irezu shite, ametsuchi wo ugokashi, me ni mienu kishin wo mo, aware to omowase, otoko onna no naka wo mo yawarage, takeki mono no fu no kokoro wo mo nagusamuru wa uta nari (NKBT 8: 93). Die in SHIRANE 2007 enthaltene Übersetzung des Vorwortanfangs (S. 149) weicht wenig von KI-McCulLough 1985 [914] ab, Ki-ACKeRMANN 2000 [914] verzichtet ganz auf die Übersetzung der beiden Vorworte. Laurel R. Rodd übersetzt den Anfang wie folgt: „The seeds of Japanese poetry lie in the human heart and grow into leaves of ten
} 
Damit sind schon zu Beginn der Geschichte der japanischen Literaturtheorie zwei zentrale und hiernach beständig neu diskutierte Topoi vorgegeben. Der im Zusammenhang der vorliegenden Abhandlung wichtigere ist das Verhältnis der im sprachlichen Kunstwerk verbalisierten Gegenstände zu den im sprachlichen Kunstwerk nicht verbalisierten Gegenständen. ${ }^{162}$ Die Verbalisierung etwa von Fauna und Flora wird als sprachliche Vergegenständlichung dessen aufgefasst, was der Mensch angesichts seiner Erfahrungen in seinem Inneren in sprachlich nicht vergegenständlichter Form empfindet (kokoro ni omou). Die Empfindung besteht als Samen (tane) a priori, vergegenständlichende Äußerungen wie etwa der Gesang (ob von einem Menschen, einem Grasmückenvogel oder einem Frosch) und seine Versprachlichung entstehen abhängig davon (als ha, Blätter) a posteriori.

Die eigentliche, als Wirkmacht verstandene Wirklichkeit kommt im Kokinshū dem, was 900 Jahre später in der Philosophie des deutschen Idealismus als die Idee bezeichnet wird, bemerkenswert nahe, wie ein Vergleich mit dem folgenden Zitat aus Teil II (Die subjektive Logik oder Lehre vom Begriff) von Hegels Wissenschaft der Logik (1812-16) zeigt.

Indem sich aber das Resultat ergeben hat, dass die Idee die Einheit des Begriffs und der Objektivität, das Wahre, ist, so ist sie nicht nur als ein Ziel zu betrachten, dem sich anzunähern sei, das aber selbst immer eine Art von Jenseits bleibe, sondern dass alles Wirkliche nur insofern ist, als es die Idee in sich hat, und sie ausdrückt. Der Gegenstand, die objektive und subjektive Welt überhaupt sollen mit der Idee nicht bloß kongruieren, sondern sie sind selbst die Kongruenz des Begriffs und der Realität; diejenige Realität, welche dem Begriffe nicht entspricht, ist bloße Erscheinung, das Subjektive, Zufällige, Willkürliche, das nicht die Wahrheit ist. ${ }^{163}$

thousand words. Many things happen to the people of this world, and all that they think and feel is given expression in description of things they see and hear" (KI-RoDD-WIXTED 1996 [914]: 35). Donald Keene übersetzt (wie bei Shirane) nur den ersten Absatz des kana-Vorwortes (KEENE 1993: 246). Oscar Benl fasst die zentralen Gedanken des Vorwortes zusammen und referiert ausführlich zu deren Quellen in der chinesischen Poetik, namentlich zum Zusammenhang mit dem „Großen Vorwort“ (Daxu 大序) des Shijing (BENL 1951: 17-23).

162 Der zweite zentrale Topos ist die grundsätzlich positive Wirkung des Liedes (uta) auf die Welt. Diese im kana-Vorwort des Kokinshū im Grunde wertneutral konstatierte Wirkung der Literatur (hier vertreten durch $u t a$ ) wird später von vielen Literaturtheoretikern als ihre Daseinsberechtigung, gar als ihr Zweck angesehen.

163 HEGEL 1986 [1812-1816]: 464. Wing-Tsit Chan weist auf die verblüffende Ähnlichkeit der Philosophie Zhuang Zhous mit Hegels Identitätskonzept hin (CHAN 1970: 183). 
Die über die Verschiedenheit der Abstraktionsstufen sowie den zeitlichen und örtlichen Abstand zwischen Tsurayuki und Hegel hinweg spürbare Nähe der Gedankengänge verweist auf deren grundlegende Bedeutung und das große Gewicht ihrer Fragestellungen: Was können und wollen wir äußern, wie können, wollen und sollen wir es äußern, und warum äußern wir uns überhaupt?

Dieser Bezug auf die Natur, die Bestimmung des gesprochenen, geschriebenen und gedichteten Wortes als Verbalisierung von a priori vorhandenen, nicht verbalisierten Kerngegenständen geschieht in keinem der genannten Texte zufällig: Der Rückgriff auf die durch Fauna und Flora vertretene Natur entspricht der Rückkehr zum Ursprung allen menschlichen Seins. Vor diesem Hintergrund ist ohne Übertreibung festzustellen, dass das kana-Vorwort des Kokinsh $\bar{u}$ Grundfragen des menschlichen Daseins im Spannungsfeld zwischen Ursprung und Äußerung thematisiert. ${ }^{164}$

\subsubsection{Empfindung ist nur durch Verbalisierung real: Das Korai fūtei shō ([Sammlung altüberkommener Stile und Formen], 1197) des Fujiwara no Shunzei (1114-1201)}

Das Korai fütei shō 古来風躱抄 ([Sammlung altüberkommener Stile und Formen], 1197) ist das literaturtheoretische Hauptwerk des Fujiwara no Shunzei 藤 原俊成 (1114-1201) und besteht zu einem großen Teil aus Auszügen aus den Lyrikanthologien Man'yōshū 8. Jh.) und Kokin wakashū (914). Auch in den Prosateilen nehmen die Darlegungen der Historie des Waka und des setsuwa einen großen Raum ein. Der im engeren Sinne theoretische Teil bildet die Einleitung, in welcher überdies dessen Gültigkeitsanspruch durch mehrfache Betonung, dass Gutes und Schlechtes an einem Gedicht nicht mit Worten zu fassen seien, eingeschränkt wird. Den Schwerpunkt der theoretischen Überlegungen Shunzeis bildet die Form (sugata), insbesondere der Wohlklang des rezitierten Waka. Shunzei betont die Besonderheit der Waka-Sprache, die Dinge ausdrücken kann, welche die Sprache der Prosa nicht erfasst.

Im unserem Zusammenhang ist von besonderem Interesse, dass Shunzei die Beziehung von nicht verbalisiertem Innerem (das er als kokoro 心 bezeichnet) und verbal Geäußertem (kotoba 言葉, wörtlich „Blätter der Sprache“) ${ }^{165}$

164 Auf diesen Punkt komme ich am Schluss der Untersuchung zurück.

165 Kono kokoro wa, toshigoro mo ika de mōshi noben to wa omou [sic!] tamauru wo, kokoro ni wa ugoki nagara kotoba ni wa idashi gataku, mune ni wa oboe nagara kuchi ni wa nobe gatakute makari suginu bekari tsuru wo この心は、年ごろもいかで申述べんとは思ふ [sic!] 給ふるを、心にはうごきながら言葉には出だしがたく、胸には覚えながら口には述べがた くてまかり過ぎぬべかりつるを (FuJIWARA-WATANABE-KoBAYASHI 2006 [1197]: 29). Bei omou tamauru kann es sich aus grammatischen Gründen nur um einen Druckfehler handeln, kor- 
nicht - wie das von ihm extensiv referierte Kokinshū (3.4.2.2) - als Substitution beschreibt, sondern auf der Grundlage des ausdrücklich erwähnten Mohe zhiguan 摩訶止観 (The great calming and contemplation, 594) ${ }^{166}$ des Zhiyi 智顗 (538-597; zweiter Patriarch der chinesischen buddhistischen Tiantai-Schule) als Synthese: Die Phänomene der Welt existierten nur, weil die Menschen deren Existenz anerkennten. Erkennten sie sie nicht an, existierten sie auch nicht. Mit Blüten (hana, gemeint sind wohl die Kirschblüten des Frühjahrs) und herbstlichen Ahornblättern $(k \bar{o} y \bar{o})$ an sich seien Anblick und Duft verbunden, doch existierten diese auch im Sinne (kokoro) des Menschen. Zwischen den beiden Sphären gebe es keine Trennung, sie bildeten vielmehr eine Einheit. ${ }^{167}$ Wie wir sehen, beginnt hier die Aufhebung der strikten Trennung von innerer (nicht verbalisierter) und äußerer (verbal geäußerter) Welt.

\subsubsection{4 „Leere“ und „Fülle“ im Gleichgewicht: Idee und Emotion im Inaka no kuawase (1680) des Matsuo Bashō}

Die Grenzen zwischen „Leere“ und „Fülle“ sind Gegenstand der vom Bashō-Schüler Takarai Kikaku 宝井其角 (1661-1707) zusammengestellten Haikai-Anthologie

rekt wäre omoi tamauru. Der selbe Fehler findet sich auch im modernen Nachdruck in NKT 2: 304: „Was dieses Herz betrifft, so denke ich in meinem Alter [im 83. Lebensjahr] zwar darüber nach, wie ich es äußern will, doch mag es vorkommen, dass etwas im Herzen sich regt und doch nicht in Blättern der Sprache [= Worten] nach außen zu tragen ist, dass man etwas im Busen empfindet, nicht aber mit dem Munde mitteilen kann und es vorübergegangen ist.“ Shunzei bezieht sich mit „Blätter der Sprache“ (kotoba) auf das kana-Vorwort des Kokinshū, wo ausdrücklich vom Herz als Samen und den Wörtern als daraus erwachsenden Blättern die Rede ist.

166 Eine Übersetzung des 1. Kapitels enthält ZHIYI-DonNER-STEVEnSON 1993. Die Übersetzung eines kleinen Auszugs bietet ZHIYI-HuRviTZ 1999.

167 „The name ,ten dharma-spheres“ applies in each case to the aggregates, objects of perception, and spheres. Their realities are different from one another. The three lowest states of existence are the aggregates, objects of perception, and spheres of tainted evil. The next three states of existence are the aggregates, objects of perception, and spheres of tainted good. [...] No one Mind comprises ten dharma-spheres, but each dharma-sphere also comprises ten dharma-spheres, giving a hundred dharma-spheres. One sphere comprises thirty kinds of worlds, hence a hundred dharma-spheres comprise three thousand kinds of worlds. These three thousand are contained in a fleeting moment of thought. Where there is no Mind, that is the end of the matter; if Mind comes into being to the slightest degree whatsoever, it immediately contains the three thousand. One may say neither that the one Mind is prior and all dharmas posterior nor that all dharmas are prior and the one Mind posterior.“ (MAIR 1994: 461). 
Inaka no kuawase 田舎之句合 ([Ländlicher Versreigen], 1680). Die Anthologie enthält 50 Haikai von Kikaku, von denen je zwei in 25 Sitzungen (ban) einander gegenübergestellt werden. Als Dichter der vorgetragenen Gedichte werden die fiktiven Figuren Nerima no nōjin („Mensch aus dem ländlichen Nerima“) und Kasai no yajin („Mann vom Feld in Kasai“) genannt. Der Gegenüberstellung folgt dann das Urteil Bashōs. Das Vorwort des Bashō-Schülers Hattori Ransetsu 服部嵐雪 (1654-1707) beginnt mit einer Erläuterung der Qualitäten des „Richters" Bashō, ${ }^{168}$ die in der Feststellung gipfelt, sein Urteilsspruch reflektiere die Philosophie des Zhuang Zhou. ${ }^{169}$ Der Leser wird also aufgefordert, die von Bashō entwickelte Vorstellung von Fiktion und Wirklichkeit mit den Augen eines Philosophen zu sehen, der die Trennung von Fiktion und Wirklichkeit aufhebt. ${ }^{170}$ Vor diesem Hintergrund erscheint Sitzung 9 des Inaka no kuawase in einem besonderen Licht. ${ }^{171}$

168 Bashō, heißt es, predige das Haikai mujin kyō 俳諧無尽経 ([Sutra von der Unerschöpflichkeit des Haikai], hier nur bildlicher Ausdruck für die umfangreiche Lehrtätigkeit des Meisters), sein Stil vereine die besten Elemente der chinesischen Poesie, namentlich das füjō 風情 (die Szenerie) des Su Dongpo 蘇東坡 (1037-1101), das share しゃれ (den eleganten Wortwitz) des $\mathrm{Du} F u$ 杜甫 (712-770) und das keshoku 気色 (das Wohlgefühl) des Huang Shangu 黄山谷 (= Huang Tingjian 黄庭堅, 1045-1105). Bashōs Dichtung sei geprägt von verhalten dezenter Dunkelheit ( $y \bar{u}$ 幽) und Gelassenheit.

169 Tatsächlich enthalten Bashōs Literaturtheorien zentrale Philosopheme des Zhuang Zhou. Allerdings ist nicht zu verifizieren, dass Bashō das Zhuangzi selbst gelesen und direkt von dort dessen Metaphorik (gūgen)-These übernommen hat. Als Quellen kommen viel eher die Theorien Sōins und Ichūs in Frage (HiROTA 1961: 680-681).

170 Die in diesem Zusammenhang am weitesten verbreitete Anekdote aus dem Zhuangzi ist die des Schmetterling-Traumes aus Kapitel 2 (Qi wu lun 齊物論). Sie lautet in Burton Watsons Übersetzung: „Once Chuang Chou dreamt he was a butterfly, a butterfly flitting and fluttering around, happy with himself and doing as he pleased. He didn't know he was Chuang Chou. Suddenly he woke up and there he was, solid and unmistakable Chuang Chou. But he didn't know if he was Chuang Chou who has dreamt he was a butterfly, or a butterfly dreaming he was Chuang Chou. Between a butterfly and Chuang Chou there must be some distinction! This is called the Transformation of Things“. (ZhuAnG-WATSON 1968 [130 v. Chr.]: 49).

171 Textgrundlage: MaTSUO-ISHIKAWA 1929 [1680]: 407. 


\begin{tabular}{|c|c|c|c|c|}
\hline \multicolumn{3}{|c|}{ Dai kyū ban 第九番 (Originaltext) } & \multicolumn{2}{|c|}{ (Übersetzung) Sitzung Nummer 9} \\
\hline$S a$ 左 & $\begin{array}{l}\text { Kabe no mugi / } \\
\text { mugura sennen wo } \\
\text { / warau to ka ya }\end{array}$ & $\begin{array}{l}\text { 壁の麦葎千 } \\
\text { 年をわらふ } \\
\text { とかや }\end{array}$ & $\begin{array}{l}\text { Zur } \\
\text { Linken }\end{array}$ & $\begin{array}{l}\text { Dass die Gerste der Mauer / bei } \\
\text { den tausend Jahren des Labkrautes } \\
\text { / lacht, wie seltsam! }\end{array}$ \\
\hline 右 & $\begin{array}{l}\text { Suribachi no / } \\
\text { sanae ho ni deru / } \\
\text { shūsha arame }\end{array}$ & $\begin{array}{l}\text { 擂鉢の早苗 } \\
\text { 穂に出る秋 } \\
\text { 社あらめ }\end{array}$ & $\begin{array}{l}\text { Zur } \\
\text { Rechten }\end{array}$ & $\begin{array}{l}\text { Im Mörser / kommen die } \\
\text { Reissprösslinge aus den Ähren } \\
\text { hervor / bald ist wohl der Tag des } \\
\text { Erntedanks im Herbste. }\end{array}$ \\
\hline $\begin{array}{l}\text { Hanshi } \\
\text { 判詞] }\end{array}$ & \multicolumn{2}{|c|}{$\begin{array}{l}\text { Kabe ni hauru mugi wa, chōkin no } \\
\text { kaisaku 晦朔 wo shirazu. Meirei 冥 } \\
\text { 霊 taichin 大椿 wo ronzuru ni } \\
\text { nitari. Mata suribachi no sanae ni } \\
\text { aki wo omou koto, kano „Futaba } \\
\text { fuku dani ogi no uwakaze“ to } \\
\text { yomitamau kokoro mo onozukara } \\
\text { nari. Sa wa kyo 虚nari, u wa jitsu } \\
\text { 実. Ka jitsu 花実 izure ka wo toran. }\end{array}$} & \multicolumn{2}{|c|}{$\begin{array}{l}\text { Was die an der Mauer wachsende Gerste } \\
\text { angeht, so ist sie wie der Morgenpilz, welcher } \\
\text { nicht den Wechsel eines Tages und den } \\
\text { Wechsel eines Monates kennt. }{ }^{172} \text { Das ist so, als } \\
\text { disputierte man über die Raupe und die große } \\
\text { Camelie. }{ }^{173} \text { Wiederum bestehen der Gedanke } \\
\text { an den Herbst beim Anblicke der Reisähren im } \\
\text { Mörser und jener im Gedicht „Selbst über die } \\
\text { jungen Blätter fegt er hinweg, der Wind im } \\
\text { Rohrschilf“ } 174 \text { enthaltene Sinn ganz von selbst. } \\
\text { Das [Gedicht zur] Linken hat Leere, jenes zur } \\
\text { Rechten Fülle. Blüte oder Samen, für welches } \\
\text { soll man sich nur entscheiden! }\end{array}$} \\
\hline
\end{tabular}

Schon die in den beiden letzten Sätzen seines Richterspruchs enthaltene Gleichsetzung der Dichotomien „Leere - Fülle“ und „Blüte - Samen“ verdient,

172 Bashō spielt hier auf eine Passage aus Abschnitt 1 (Xiaoyao you 逍遥遊, „Free and easy wandering“) des Zhuangzi an. Zhuang Zhou doziert dort, dass große Entfernungen nicht von kleinen Lebewesen überwunden, zeitaufwändiges Verstehen nicht von kurzlebigen Wesen geleistet werden kann, und schließt dann wie folgt an: 朝菌不知晦朔、蟪蛄不知春秋。(Zhuangzi zhu 莊子注 1: 3b, SKQS-Edition). ,The morning mushroom knows nothing of twilight and dawn; the summer cicada knows nothing of spring and autumn“ (ZHUANG-WATSON 1968 [ca. 130 v. Chr.]: 30).

173 Bashō zitiert indirekt aus dem soeben schon angeklungenen Abschnitt des Zhuangzi, wo es heißt: 楚之南有冥靈者。以五百歳為春、五百歳為秋。上古、有大椿者。以八千歳為春、八 千歳為秋。而彭祖乃今以久特聞。衆人匹之、不亦悲乎。(Zhuangzi zhu 莊子注 1: 3b, SKQSEdition). In der folgenden Übersetzung Burton Watsons entspricht der oben mit „große Camelie“ wiedergegebenen Pflanze „rose of Sharon“. „South of Ch'u there is a caterpillar which counts five hundred years as one spring and five hundred years as one autumn. Long, long ago there was a great rose of Sharon that counted eight thousand years as one spring and eight thousand years as one autumn. They are long-lived. Yet P'eng tsu alone is famous today for having lived a long time, and everybody tries to ape him. Isn’t it pitiful!“ (ZHUANG-WATSON 1968 [ca. 130 v. Chr.]: 30). „P’eng tsu [Peng zu 彭祖]“ ist eine Art chinesischer Methusalem.

174 Das Gedicht ist nicht verifizierbar. 
als terminologische Besonderheit festgehalten zu werden. Im Zusammenhang der vorliegenden Abhandlung ist allerdings die in der Schlussfrage implizierte Gleichwertigkeit von „Leere“ und „Fülle“ von noch größerer Bedeutung, denn sie wirft die Frage nach dem Verhältnis der beiden Begriffe in der Haikai-Dichtung erneut auf. Satō Katsuaki kommt in seiner Analyse der Sitzung Nr. 9 zu dem überzeugenden Schluss, dass Bashō den Unterschied des ideenbasierten Gedichts zur Linken und des auf tatsächlichen Emotionen basierenden Gedichts zur Rechten zwar durchaus wahrnimmt, es ihm aber nicht um die Entscheidung zwischen „Leere“ und „Fülle“ gehe, sondern um deren Verschränkung ineinander. Demnach geht es Bashō also darum, in welchem Maße in einem auf einer fiktiven Konstruktion basierenden Gedicht der „Leere“ die andere Seite, die „Fülle“ ausgedrückt ist, oder in welchem Maße in einem von tatsächlichen Emotionen oder Situationen ausgehenden Gedicht der „Fülle“ die andere Seite, die über die Emotionen hinausgehende Tiefe, ausgedrückt ist. ${ }^{175}$

Im vorstehend analysierten Inaka no kuawase wird die theoretische Auflösung von Dichotomien als möglich und notwendig beschrieben. Im folgenden blicken wir von hier aus zurück in die Begriffshistorie und gewinnen den Eindruck, dass die dabei zu beobachtenden „harten“ Dichotomien teilweise derart im Formalismus erstarrt und rigoros sind, dass sie nicht mehr allgemein literaturtheoretische Problem lösen können und Bashō es als notwendig ansehen musste, die Dichotomien aufzuweichen.

\subsubsection{Gestalt‘ in Literaturtheorien von den Anfängen bis 1850}

„Gestalt“ steht hier stellvertretend für Wörter wie kei und katachi 形 (Varianten: katachi 容, katachi 像) („Gestalt“, „Form“), tei und tai 体 („Körper“) sowie shoku 色 („Farbe“). In japanischen Literaturtheorien zur Dichotomie „Fiktion - Wirklichkeit“ treten solche Wörter häufig in Verbindungen wie mukei 無形 („Gestaltloses“) und ukei 有形 (,Gestalthaftes“) auf, meist wird dann das „Gestaltlose“ mit „Leere“, das „Gestalthafte“ mit „Fülle“ assoziiert. Dass übrigens das „Gestalthafte" in diesem Zusammenhang keineswegs immer auf das Materielle, das „Gestaltlose“ keineswegs immer auf das Immaterielle verweist, wird in diesem Abschnitt zu zeigen sein.

175 SATŌ 2006: 222-223. 


\subsubsection{Gestaltlose und gestalthafte Erscheinungen der Natur in ihrer Verbindung in der Lyrik: Das Xinding shige (7. Jh.) des Cui Rong}

Die Dichotomie „Gestaltlosigkeit - Gestalthaftigkeit“ (wuxing 無形 - youxing 有形) fand eine ihrer frühesten Verwendungen in der chinesischen Poetik in der folgenden Passage aus dem Xinding shige 新定詩格 ([Neu festgelegte Regeln der Poesie], Ende 7. Jh.) des Dichters Cui Rong 崔融 (653-706).

Eleganz nenne ich es, wenn [das Gedicht] im vorausgehenden Vers eine Szenerie der Natur, im darauf folgenden Vers den Namen einer Person enthält; oder aber wenn es im vorausgehenden Vers von Wind und Himmel erzählt, im darauf folgenden Vers von Bergen und Gewässern. Mein Grund dafür ist, dass Wind und Himmel keine Gestalt haben und nicht sichtbar sind, Berge und Gewässer jedoch Spuren hinterlassen, welchen man nachgehen kann. Das Gestalthafte mit dem Gestaltlosen zu paaren, das sind Beispiele, welche ich für elegant halte. ${ }^{176}$

Der Passus aus dem Xinding shige ist ebenfalls im oben besprochenen Bunkyō hifu ron enthalten. ${ }^{177}$ Direkt an die hier zitierte Passage aus dem Xinding shige des Cui Rong schließt sich im Bunkyō hifu ron das folgende Zitat aus dem Shiyi yijuan 詩議一卷 ([Erörterung der Poesie in einem Bande], Ende 8. Jh.) des Mönchs Jiaoran 皎然 (720-805?) an.

Es sagte jemand: Wind und Schatten, Herz und Farbe ${ }^{178}$ kann man dem Gestaltlosen gegenüberstellen, aber man kann es auch dem Gestalthaften gegenüberstellen. ${ }^{179}$

Mit anderen Worten: Gestaltlosigkeit und Gestalthaftigkeit sieht Jiaoran relativ. Im Übrigen sei die Kontrastierung konkreter, gestalthafter Gegenstände (shi) und idealisierter, gestaltloser $(x u)$ Dinge $^{180}$ ein akzeptables poetisches Mittel. Nach

176 Originaltext: Myō to wa, zenku busshoku, kōku jinmei to ii, arui wa zenku kaze sora wo katari kōku yama mizu. Kono gotoki rei wo myō to nazuku. Naze to naraba, kaze to sora wa sunawachi katachi naku shite miezu, yama to mizu wa sunawachi ato atte tazunu bekereba nari. Yūkei wo motte mushoku ni tsui shi, kono gotoki rei wo myō to nazuku. 眇者、前句物色、後句人 名、或前句語風空、後句山水。如此之例、名眇。何者、風與空則無形而不見、山與水則有蹤 而可尋。以有形對無色、如此之例、名為眇。(KŪKAI-KonISHI 1953 [810-824]: 112). Bei der hier transkribierten Japonisierung des chinesischen Textes weicht KūKAI-KonISHI 1953 [810-824] von seiner Version KonISHI 1946 geringfügig ab.

177 Siehe Abschnitt 3.4.2.1.

178 „Farbe“ für shoku 色, hier im Sinne von „Gestalt“.

179 Originaltext: Aru iu. Fūkei shinshoku nado, motte kyo ni tai subeku, mata motte jitsu ni tai subeshi. 或曰。風景心色等、可以對虚、亦可以對実。(KŪKAI-KoNISHI 1953 [810-824]: 112). Eine japonisierte Fassung bietet KoNISHI 1946: 24.

180 Shuang xushi dui 雙虚実対 („Leere und Fülle einander in Paaren gegenüberstellen“). Das bei Konishi zitierte, von Jiaoran eingeführte Beispielgedicht vergleicht einen Verstorbenen in seinem Kommen und Gehen (laiwang 来往) mit aufgelösten (san 散) Regenwolken (yunyu 雲 雨) und stellt sie Himmel und Bergen (kongshan 空山) gegenüber. Die Regenwolken werden 
Jiaoran stabilisiert sich der Begriffsgehalt des Terminus xushi und bezeichnet die Gegenüberstellung von Gestaltlosem und Gestalthaftem als ästhetische Norm. So erläutert beispielsweise der Literatenbeamte Luo Dajing 羅大経 (fl. 1248) in seiner Miszellensammlung Helin yulu 鶴林玉露 ([Trautropfen im Kranichwald], 1248) ${ }^{181}$ anhand eines Gedichtes des gefeierten Tang-Dichters Du Fu 杜甫 (712-770) die perfekte Verbindung von Gestaltlosem und Gestalthaftem. ${ }^{182}$

\subsubsection{2 „Leere“ ist das Gestaltlose, „Fülle“ ist das Gestalthafte - Dichtung soll „Leere“ und „Fülle“ verbinden: Das Fupu (9. Jh.) als Rüstzeug des angehenden Beamten}

Während der Eingangsprüfungen für chinesische Beamten (chin. keju 科挙, japan. kakyo) mussten Kandidaten in der Tang-Zeit (618-907) unter anderem die Befähigung zum Dichten von lüfu 律賦 („regulierte Prosagedichte“) nachweisen, wobei Silbenzahl, Reim und Signifikant streng festgelegten Normen unterworfen waren. Diese Befähigung wurde als Beweis der technischen Eignung für das Verfassen amtlicher Texte sowie der charakterlichen Eignung des Kandidaten gesehen. ${ }^{183}$ Von einer Vielzahl leitfadenartiger Verzeichnisse dieser

dabei als konkret und geformt gesehen, das Kommen und Gehen als idealisiert und formlos (KoNISHI 1946: 24).

181 Helwig Schmidt-Glintzer sieht das Helin yulu als beispielhaften Ausdruck des Literatenbeamten-Ideals der Song-Zeit, in dem der Verfasser als unabhängiger Beobachter und zugleich bewertender Kritiker private Geschichtsschreibung betrieb (SCHMIDT-GLINTZER 1990: 357).

182 Luo Dajing verteidigt das zweite von drei Gedichten des Zyklus Pingii sanshou 屏跡三首 ([Drei Gedichte auf das Verbergen von Spuren], 762) gegen einen nicht namentlich genannten Kritiker. Du Fus kleiner Zyklus resümiert das Leben eines sich selbst als nutzlos sehenden Trunkenboldes, der aus einsamer Ferne das ohne ihn weitergehende Leben beobachtet. Die Verse 3 und 4 des zweiten Gedichtes lauten Sōma uro ni fukashi. Enjaku nakaba seisei su. 桑麻 深雨露。燕雀半生成。 (Tianji zhuan 天集伝 [Bd. 1, Biografien], 3. Faszikel, Abschnitt Shencheng chui $x u$ 生成吹噓; LuO-NAGASAWA 1976 [1248]: 28), „Maulbeer und Hanf sind tief in Regen und Dunst versunken, Schwalbe und Sperling sind halb [erst] entschlüpft und halb [schon] erwachsen.“ Der Kritiker habe nun bemängelt, dass es hier keine Zuordnung von Gestaltlosem und Gestalthaftem gebe (kyojitsu rui sezu 虚実不類). Dem hält Luo Dajing entgegen, dass es in Vers 4 nicht auf die Vögel ankomme, sondern auf die Begriffe „Entschlüpfen“ und „Erwachsen“, die gestaltlose Prozesse beschrieben und deren Gegenüberstellung zu der gestalthaften Szenerie des regennassen Dickichts aus Maulbeeren und Hanf des Verses 3 sehr wohl passe (LUO-NAGASAWA 1976 [1248]: 28).

183 ELMAN 2013. Dass Literatur und Musik nach traditioneller konfuzianischer Anschauung gar direkt Auskunft über die moralisch-politische Situation eines Staates geben, wird schon im Abschnitt Xiangong 襄公 (29. Jahr) des Chunqiu zuozhuan 春秋左伝 (kurz nach 479 v. Chr.) vom Botschafter Zha 札 des Fürstentums $\mathrm{Wu}$ 吳 berichtet: Anhand der ihm vorgetragenen Lieder habe er moralische Qualität und Zustand des jeweils durch sie repräsentierten Staates er- 
Normen sind nur die Titel auf uns gekommen, nur wenige Texte haben die Zeiten überdauert. Einer davon ist das (allerdings in nur wenigen Exemplaren nachweisbare) Fupu 賦譜 ([Verzeichnis von Prosagedichten], 9. Jh.) eines unbekannten Kompilators. ${ }^{184}$ Gerade der Leitfadencharakter der Kompilation sowie die Tatsache, dass der Verfasser für unwichtig genug gehalten wurde, um nicht namentlich genannt zu werden, rechtfertigen die Erwartung, dass das Fupu einen Einblick in das allgemeine Literaturverständnis der Tang-Zeit erlaubt. Behandelt werden hier eben nicht Texte mit höchsten sozialem Prestige, sondern zweckgebundene, im Prinzip von jedem produzierbare Gesellenstücke, die jene von einem Beamten im Berufsalltag verlangten handwerklichen Fähigkeiten nachweisen sollten. Repräsentativ ist die Kompilation auch, weil die zitierten Beispielgedichte erfolgreicher Prüfungskandidaten die gesamten dreihundert Jahre der Tang-Dynastie (618-907) abdecken. Das Fupu gliedert sich in zwei Teile, von denen der erste Teil formale Aspekte behandelt, der zweite die inhaltliche Frage von „Leere“ und „Fülle“ (xushi), insbesondere die Nachbildung des Formlosen (wu xingxiang wu 無形像物) als $x u$ 虚. Demgegenüber wird die Nachbildung des Formhaften (you xingxiang wu 有形像物) als shi 実 bezeichnet. In der uneigentlichen Redeweise (biyu de biaoxian 比喻的表現) verwende man das Formhafte (shi), um das Formlose $(x u)$ zu vergegenständlichen.

(15) Leere. Was das Form- und Gestaltlose betrifft, so teilt man [damit] prinzipielle Sachverhalte mit oder erläutert sie anhand dessen. Es handelt sich um [Aussagen] von der Art wie [1] in dem Gedicht „Das große dao ist kein Gefäß“, [wo es heißt:] „Was das dao angeht, so erreicht man es auf jeden Fall von selbst, während das Gefäß erst in Abhängigkeit von Dingen entsteht. Das ist gerade so wie jemanden vom Tode retten und dadurch Gutes tun. Wie sollte man dem in Abhängigkeit von Anlässen einen anderen Namen geben?“; [oder wie] [2] in dem [Gedicht] „Naturveranlagung und Erlerntes, Nähe und Ferne“, [wo es heißt] „Ach! Vom Menschen ganz unten bis hin zum Edelmann ganz oben, bei allen entsteht die Tugendhaftigkeit aus der Zurückhaltung, doch die Naturveranlagung trennt sich vom Erlernten. Wenn man lernt und Beständiges hervorbringt, so ist das im Grunde dasselbe wie Gutes und Schlechtes dazu zu bringen, sich voneinander $\mathrm{zu}$ scheiden. Sich zurückzuhalten, steht am Anfang, und man muss auf jeden Fall die Verflechtung von Gutem und Schlechtem durchschauen.“"185

fassen können. Dies bedeutet vor allem, dass Musik wie Literatur als Maßstab des kulturellen Niveaus eines Staates gesehen und damit für wichtig erachtet wird. Vor diesem Hintergrund kann es nicht verwundern, dass insbesondere Beamte das literarische Handwerk in abprüfbarer Weise zu beherrschen hatten.

184 NAKAZAWA 1967 bietet einen japonisierten und mit zahlreichen philologisch wertvollen Hinweisen angereicherten modernen Druck des im Original handschriftlich überlieferten Textes.

185 Kyo. Keishō naki no koto wa, mazu sono jiri wo jo shi, motte hatsumei su-bekarashimu. [1] „Daidō wa ki narazu“ ni iu, ,Dō mizukara kanarazu toku shi, utsuwa wa mono ni yotte naru. Masa ni 
Das Gegenstück zur dieserart gedachten „Leere“ wird im Fupu wie folgt erläutert.

(16) Fülle. Was das Form- und Gestalthafte angeht, so bringt es eine dingliche Gestalt nach außen, gibt ihrem Wesen einen Körper. Es handelt sich um [Darstellungen] von der Art wie [1] „Es fällt Licht durch den Zwischenraum, wovon die Form bestimmt wird“ im [Gedicht] Xichen 隙塵, oder [2] „Der eingespannte Ochse reiht sich hier ein, zusammen mit der Erde schafft er das Schöne“ im [Gedicht] Tu niu 土牛 und [3] „Im Osten steht der volle Mond, in seinem Lichte entfaltet sich der Duft des Zimtbaumes“ im [Gedicht] Yuezhong gui 月中桂. Zwar haben sie Form und Gestalt, ihr Sinn aber besteht im Vergleiche, sie ziehen deren dingliche Gestalt heran und legen damit den prinzipiellen Sachverhalt dar. [...] Was Wasser, Stein, Hahn und Vierspänner anbetrifft, so gehören sie zur Fülle, die mahnenden Worte aber zum Leeren. So also zieht man die Fülle heran, um damit das Leere zu verifizieren. ${ }^{186}$

shi wo mamorite, motte zen wo nasan to, ani toki ni shitagaite na wo kaen ya!‘ nari, [2] „Seishū sōkintō" ni iu, ,Aa, shita wa hito yori, ue kun ni tassuru made, mina toku wa shin wo motte tachi, shikōshite sei wa shū ni yotte Wakaru. Naraeba jō wo shōji, masa ni zen’aku wo shite kubetsu seshimen to! Kore wo tsutsushimu koto hajime ni ari, kanarazu ya zehi no kyūfun wo benzu. ' no rui no gotoki nari. 虚. 無形象之事、先叙其事理、令可以発明。若 [1] 「大道不器」云、「道自必得、器因物 成。将守死以為善。豈従時而易名。」[2]「性習相近遠」云「噫、下自人、上達君、咸徳以慎 立、而性由習分。習而生常、将俾乎善悪区別。慎之在始、必弁乎是非紏紛。」之類也。

(NAKAZAWA 1967: 230). [1] ist ein auf das Kapitel Xueji 學記 des Liji (Buch 18) verweisendes Gedicht unbekannter Verfasserschaft. Die einschlägige Passage des Liji lautet: 君子曰、大德不官、大道不 器、大信不約、大時不齊。察於此四者、可以有志於學矣。 (Liji zhushu 禮記註疏 36: 25a-25b, SKQS-Edition). „A wise man has said, ,The Great virtue need not be confined to one office; Great power of method need not be restricted to the production of one article; Great truth need not be limited to the confirmation of oaths; Great seasonableness accomplishes all things, and each in its proper time.' By examining these four cases, we are taught to direct our aims to what is fundamental“ (LEGGE 1885: 91). [2] ist das Gedicht Xingxi xian jinyuan 性習相近遠 von Bo Juyi 白居易 (772846). Der Titel spielt auf Lunyu 17 an, wo Kongzi von der grundsätzlich guten Natur der Menschen und der Notwendigkeit, sie durch Kultivierung herauszuarbeiten, spricht. Es heißt dort: 子曰、性 相近也、習相遠也。 (Lunyu zhushu 論語注疏 17: 2b, SKQS-Edition). „The Master said, ,By nature, men are nearly alike; by practice, they get to be wide apart.““ (LEGGE 1900 [5. Jh. v. Chr.]: 255). Das auf dieses Zitat anspielende, im Fupu enthaltene Prosagedicht wurde immerhin für so bedeutend gehalten, dass es in Kapitel 656 der von Dong Gao 董誥 (1740-1818) kompilierten Anthologie Qinding quan Tang wen 欽定全唐文 ([Kaiserlich befohlene Anthologie aller Texte der Tang], 1814) aufgenommen wurde.

186 Jitsu. Keishō aru mono wa, sunawachi sono busshō wo kiwame, sono keisei wo tai su. [1] „Gekijin“ ni iu ,Kore suki hikari ari, kore chiri sore yoru.‘ [2] „Dogyü“ ni iu, ,Fukugyū wa kore ni narabi, tsuchi wo gō shite bi wo nasu.‘, [3] „Getsujū kei“ ni iu, ,Tsuki higashi ni michi, kei sono naka ni kōbashi. ' nado no gotoki kore nari. Keishō ari to iedomo, i hiyu ni areba, sunawachi sono busshō wo hikite, motte jiri wo shō su. [...] Mizu, ishi, niwatori, shi wa jitsu, shikōshite nakangen wa kyo nari. Yue ni jitsu wo hikite kyo wo shō su nari. 有形象之物、則究其物象、体其形勢。若 [1]「隙塵」云、「惟隙有光、惟塵是依。」 [2]「土牛」云、「服牛是比、合土成美。」 [3] $\ulcorner$ 月中桂」云「月満於東、桂芳其中。」等是也。雖有形象、意在比喻、則引其物象、以証事 理。[...] 水石鶏駆者実、而納諫言者虚。故引実証虚也。 (NAKAZAWA 1967: 230). Alle drei Gedichte werden aus dem Qinding quan Tang wen (Anm. 186) zitiert. Gedicht [1] (Xichen 隙塵 [Ge- 
Der beinahe ein Jahrtausend später entstandene im folgenden $\mathrm{zu}$ besprechende Text berührt denselben Gedanken: Auch das Immaterielle kann in einem fiktionalen Text in einer bestimmten Gestalt konkretisiert werden.

\subsubsection{Worte der Fülle bezeichnen konkrete Erscheinungen der Welt: Das Tanka senkaku (1834) des Tachibana Moribe}

Der kokugaku-Gelehrte Tachibana Moribe 橘守部 (1781-1849) gehört zu den Vertretern der Spätphase der Schule der „Landesstudien“, die sich nach dem Tod des Motoori Norinaga aufspaltete. Unter anderem bildete sich unter der Führung von Norinagas Sohn Motoori Ōhira 本居大平 (1756-1832) ein weniger das Kojiki (ca. 712) als mehr die Waka-Poesie zum Schlüssel des „alten Weges“ des Götterzeitalters in den Mittelpunkt stellender Flügel sowie unter der Führung von Hirata Atsutane ein Flügel, der zwar den Schlüssel nicht wie Norinaga allein im Kojiki sah, andererseits aber Ōhiras Konzentration auf die Waka-Dichtung missbilligte. Tachibana Moribe ist nicht eindeutig einem der beiden Flügel zuzuordnen. Moribes Erstlingswerk Yamabiko zōshi 山彦冊子 (Book of the Mountain God, 1831) steht zwar als diachronisch angelegte Studie zur semantischen Entwicklung und zur ursprünglichen Bedeutung des japanischen Wortes waka 和歌 (,japanisches Lied“) ganz in der von Norinaga begründeten Tradition, ${ }^{187}$ andere Werke weisen Moribe allerdings als Praktiker und Theoretiker der Waka-Dichtung aus, vorzüglich das Itsu no kotowaki 稜威言別 (Distinguishing the August Way, verf. 1845, gedr. 1850), ${ }^{188}$ ein Kommentar zu den im Kojiki und im Nihon shoki (720) enthaltenen Gedichten. Aufschlussreich in Bezug auf Moribes Auffassung von der Dichotomie „Fülle - Leere“ ist die im Folgenden übersetzte Passage aus dem Tanka senkaku 短歌撰格 ([Ausgewählte Regeln der Tanka-Dichtung], 1834 entstanden, Erstdruck 1875). Moribe beschäftigt sich in dieser Abhandlung mit den

\footnotetext{
kijin], [Lücke und Wesen]) stammt von Jiang Fang 蒋防 (792-835) und ist in Band 719 des Quan Tang wen enthalten. Es schildert Wolken als Verbindung von Wassertropfen und Lücken, die je nach Jahreszeit verschiedene Formen annehmen und darin die verschiedenen Abschnitte des menschlichen Lebens verbildlichen. Gedicht [2] (Tu niu fu 土牛賦 [Dogyū fu], [Prosagedicht über Erde und Ochse]) von Chen Zhongshi 陳仲師ist in Band 716 des Quan Tang wen enthalten, besingt die schöpferische Arbeit des Bauern und legt dar, dass der Ochse im selben Maße wie die von ihm gepflügte Erde an der Schöpfung des Guten beteiligt sei. Gedicht [3] (Yuezhong gui 月中桂 [Getsujū kei] [Der Zimtbaum im Mondenschein]) von Yang Hongzhen 楊宏真 ist in Band 722 des Quan Tang wen enthalten und besingt den Mondschein und den Duft des Zimtbaumes als Ausdruck einer harmonischen Stimmung.
}

187 BuRnS 2003: 158-186 (Chapter 6: Tachibana Moribe: Cosmology and Community). 188 Burns' Angaben zu Titellesung und Datierung (Burns 2003: 168) sind fehlerhaft. 
Kompositionsregeln der Waka-Dichtung (kukaku 句格) und führt zur Wortwahl aus:

An dieser Stelle will ich wie folgt die Unterscheidung zwischen Wörtern der Fülle und der Leere versuchen. Zunächst einmal halte ich Wörter, die alle nur möglichen Gegenstände zwischen Himmel und Erde [bezeichnen], für Wörter der Fülle: in vier Gruppen zusammengefasst also Zeiten, Orte, Geschehnisse und Künste sowie gestalthafte Gegenstände. Zeiten sind etwa Frühjahr und Herbst, Tag und Nacht, Jahre und Monate sowie Einst und Jetzt. Orte sind etwa Himmel und Erde, Berge und Gewässer, bekannte Orte, Ruinen alter Gebäude sowie Amtsgebäude. Geschehnisse und Künste sind etwa Riten und Musik, Feste und Glückwunschzeremonien, militärische Expeditionen, Glückliches und Unglückliches, Moral sowie Handfertigkeiten. Was im Allgemeinen die darstellende Kunst betrifft, so [sind] sie je nach dem Einsatz der Gestalt die Fülle oder das Leere. [...] Wörter der Leere fallen aus den vorgenannten Klassen heraus und bezeichnen [Dinge], welche keine Gestalt und keine Form haben, für das Auge nicht sichtbar, mit den Fingern nicht zeigbar sind - es sind einfach nur Wörter. ${ }^{189}$

Dabei trennt Moribe nur scheinbar nicht explizit zwischen Signifikant und Signifikat. Dieser täuschende Eindruck ist einer Eigenart des japanischen Sprachgebrauchs geschuldet: Sicher ergänzbare Prädikate wie „bezeichnen“ werden häufig als fakultativ betrachtet und weggelassen. Ungleich auffälliger ist die Kategorisierung von Bezeichnungen für nach unserem Verständnis form- und gestaltlose Abstrakta wie „Zeit“ (im Sinne von Jahreszeit und Klima), „Glückliches und Unglückliches“, „Geschehnisse“ und „Künste“ als „Wörter der Fülle“ (jitsugo), denen Moribe Bezeichnungen für andere, auch nach seinem Verständnis form- und gestaltlose Abstrakta als „Wörter der Leere“ (kyogo) gegenüberstellt. Dies ist nicht etwa eine logische Inkonsistenz, sondern zeugt davon, dass für Moribe das Vorstellbare und das Vorgestellte eben nicht Abstrakta, sondern Konkreta sind. Ist das semantische Feld bei den „Wörtern der Fülle“ (Konkreta) derart weit abgesteckt, bleiben als „Wörter der Leere“ (Abstrakta) nurmehr Be-

189 Koko ni mata, jitsugo, kyogo wo kokoromin tote, sore wa wakachitaru yō, mazu tenchi no aida, ari to arayuru mono no kagiri wo ba, jikō, shoi, jigei, bukkei to, yottsu ni tsuzume wakachite, kore wa jitsugo to su. Jikō to wa shunjū, nichiya, nengetsu, kokin nado nari. Shoi to wa, tenchi, sansui, meisho, kyūseki, kanshitsu nado nari. Jigei to wa, reigaku, saishuku, gunryo, kikkyō, dōtoku, gigei nado nari. Oyoso kore taigei no ue wa, taiyō no tsukaizama ni yorite, jitsu tomo kyo tomo nareri. [...] Kyogo to wa, migi no hinrui ni morete, tai naku, katachi naku, mi ni miezu, yubi ni mo sasarezaru, tada no kotoba ni iu. こっに又。実語。虚語を試みんとて、其は わかちたるやう。先づ天地の間。ありとあらゆる物の限りをバ。時候。處位。事芸。物形 と。四つに約め分かちて。是は実語とす。時候と八春秋。日夜。年月。古今等なり。處位と 八。天地。山水。名所。旧跡。官室などなり。事芸と八。礼楽。祭祝。軍旅。吉凶。道徳。 技芸等也。凡此態芸のうへ八。体用のつかひざまによりて。実とも虚ともなれり。[...] 虚語 と八。右の品類にもれて。体なく、形なく、目に見えす。指にもさっれざる、たぶの言葉に 云。(TACHIBANA 1875-II: 2a-2b; TACHIBANA-Kyūsojin 1992 [1875]: 362). 
zeichnungen grammatischer Funktionen (etwa Subjekt- und Objektbezeichnungen durch Partikel sowie Hilfsverben) übrig. Waka-Dichtung wird folglich zu einer die ganze physische und metaphysische Welt umspannenden Wortkunst.

Wir haben hiermit einige chinesische und japanische Literaturtheorien kennengelernt, deren Kernbegriff ,Gestalt‘ statischen Charakter hat und jenen immateriellen oder materiellen der Welt vertritt, auf den dynamische Kräfte einwirken. Um diese Kräfte geht es im folgenden Abschnitt.

\subsection{4 ,Dynamik` in japanischen Literaturtheorien}

„Dynamik“ steht hier stellvertretend für japanische Wörter wie $k i$ 気 („Äther“), $k i$ $r y o k u$ 気力 („Kraft des Äthers“), dō 動 („Bewegung“) und ryūkō 流行 (,Strömung“) sowie weiterer Protagonisten und deren Antagonisten in diesem semantischen Feld. In auf die Dichotomie „Fiktion - Wirklichkeit“ bezogenen vormodernen Literaturtheorien verbinden sich diese Wörter zu Dichotomien wie dōshi 動止 („Bewegung und Innehalten“) und fueki ryūkō 不易流行 („Unwandelbares und Dahinströmendes“). Alle diese Wörter und Phrasen entstammen der chinesischen Philosophie. Im folgenden sollen drei Beispiele die Möglichkeiten der Umsetzung dieser Termini in japanischen Literaturtheorien zur Dichotomie „Leere - Fülle“ verdeutlichen.

\subsubsection{Verharren in der Leere und Bewegung in der Fülle: Das Nijūgo kajō (1736) des Kagami Shikō}

Kagami Shikō 各務支考 (1665-1731) entwickelte seine Theorie von „Leere und Fülle“ (kyojitsu) auf der Basis der von seinem Lehrer Bashō in dessen späten Jahren entwickelten Theorie von der „Wahrhaftigkeit der Eleganz“ (fūga no makoto 風雅のまこと). ${ }^{190}$ Doch das folgende Zitat aus seinem Nijūgo kajō 二十五 箇条 ([Fünfundzwanzig Paragrafen der Haikai-Dichtung], 1736) rechtfertigt Horikiri Minorus Annahme weiterer Einflüsse, namentlich seitens der „Blüte Samen“-Theorie (kajitsu ron 花実論) der traditionellen Waka-Schule, Zhu Xis Theorie vom „Prinzip des dao“ (dao li, jap. dōri 道理), Zhuang Zhous Weltsicht, das buddhistische Denken über die „Leere“ ( $k \bar{u}$ 空) und das Zen-buddhistische Denken des „Nichtsein“ ( $m u$ 無). ${ }^{191}$

Die Zehntausend Dinge verharren in der Leere, wirken aber in der Fülle. Sie können nicht in der Fülle verharren und in der Leere arbeiten. Die Fülle bringt sich selbst zum Erscheinen und hat etwas an sich, das die Menschen gegen sich aufbringt. So ist es zum Beispiel

190 HORIKIRI 1968: 26; 34.

191 HORIKIRI 1968: 34. 
beim Bedauern über das Herabfallen der Blüten oder beim Bedauern über die Neigung des Mondes so, dass es tatsächlich zu bedauern die Fülle des renga ist, es im Leeren zu bedauern, die Fülle des haikai. Allgemein ist zu sagen, dass es sich beim Verfassen von Gedichten und renga um geschicktes Lügen handelt. Das Vorhandensein von Fülle in der Leere nenne ich Stil, das Vorhandensein von Leere in der Fülle nenne ich [verderbliche] Gewandheit in irdischen Dingen, das Vorhandensein von Fülle in der Fülle nenne ich Menschlichkeit, Aufrichtigkeit, Respekt und Weisheit. Ich meine, dass es in der Welt selten vorkommt, dass Leere in der Leere vorhanden ist, vielleicht kommt es aber doch häufig vor. Ich kann in Bezug auf diesen Menschen sagen, dass er in die Tradition meiner Schule eingereiht ist." ${ }^{192}$

Hier haben wir nun eine Verbindung mehrerer, nicht mehr linear zu einer einzelnen Quelle zurückzuverfolgender Begriffe: „Fülle“ (jitsu), „Leere“ (kyo), „Blüte“ (ka, hana), „Lüge“ (uso 嘘) sowie die konfuzianischen Tugenden Menschlichkeit (jin 仁), Aufrichtigkeit (gi 義), Respekt (rei 礼) und Weisheit (chi 智). Diese Verbindung überschreitet gewissermaßen die „fachlichen Grenzen“ einzelner philosophischer und ethischer Schulen und erzeugt - die Absicht der Schaffung eines synchronen Systems vorausgesetzt - bewusst ein neues Teilfeld der Literaturtheorie, welche hierdurch beginnt, sich gegenüber dem philosophischen Überbau selbständig zu machen.

\subsubsection{Das „Unwandelbare“ und das „Dahinströmende“ (fueki ryūkō) seit dem Kyorai shō (1775) des Mukai Kyorai}

Das Kyorai shō 去来抄 ([Aufzeichnungen des Kyorai], 1775) des Mukai Kyorai 向井 去来 (1651-1704) vermerkt, dass sein Lehrer Matsuo Bashō sein ästhetisches Ideal anhand des literaturtheoretischen Begriffs fueki ryūkō 不易流行 („Unwandelbares und Dahinströmendes“) seit dem Winter 1690 in Lehrgesprächen mündlich zu erläutern begann, also kurz nach der Rückkehr von jener einjährigen Wanderung, die eine deutliche Zäsur in seinem Leben und Schaffen darstellte. Während diese

192 Banbutsu wa kyo ni ite jitsu ni hataraku. Jitsu ni ite kyo ni hataraku bekarazu. Jitsu wa onore wo tate, hito uramuru tokoro ari. Tatoeba hana no chiru wo kanashimi, tsuki no katabuku wo kanashimu mo, jitsu ni oshimu wa renga no jitsu nari. Kyo ni oshimu wa Haikai no jitsu nari. Somosomo, shiika-renga to iu mono wa, jōzu ni uso wo tsuku koto nari. Kyo ni jitsu aru wo bunshō to ii, jitsu ni kyo aru wo sechiben to ii, jitsu ni jitsu aru wo jin gi rei chi to iu. Kyo ni kyo aru mono wa yo ni mare ni shite, arui wa mata ōkarubeshi. Kono hito wo sashite waga ie no denju to iubeshi. 万 物は虚に居て実に働く。実に居て虚に働くべからず。実は己を立て、人をうらむる所有。譬 ばはなのちるをかなしみ、月のかたぶくをかなしむも、実に惜しむは連哥の実なり。虚に惜 しむは俳諧の実なり。抑、詩哥・連哥といふ物は、上手に嘘をつく事なり。虚に実あるを文 章と言、実に虚あるを世智弁と言、実に実あるを仁義礼智と言。虚に虚ある者は世に稀にし て、あるひは又多かるべし。此人をさして我家の伝受と言べし。 (KAGAMI-ŌISO 1970 [1736]: 68). Wen Kagami mit kono hito (“dieser Mensch,,) meint, ist nicht zu klären. 
Zäsur in der literarischen Praxis aber erst vier Jahre später im Oku no hosomichi 奥の細道 (Auf schmalen Pfaden durchs Hinterland, 1694) ihren schriftlichen Niederschlag fand, ${ }^{193}$ sind erste Ansätze einer Theorie vom „Unwandelbaren“ und „Dahinströmenden“ in den Formulierungen bandai fueki 万代不易 (,über Zehntausend Zeitalter unveränderlich“) in einem auf Ende 1690 datierten Brief an seinen Schüler Kyorai ${ }^{194}$ nachweisbar. Die Vorstellung vom Verhältnis zwischen „Unwandelbarem“ und „Dahinströmendem“ wurde in der japanischen Literaturtheorie allem Anschein nach zuerst von Bashō in die Formulierung fueki ryūkō gegossen, die Vorstellung selbst aber geht zurück auf die Dualität von Prinzip (li 理) und Äther ( $q$ 気) des durch Zhu Xi geprägten japanischen Neokonfuzianismus: ${ }^{195}$ Eine konkrete Entität, in Bashōs Fall das Haikai, enthält das unveränderliche, statische Element einer Essenz und das veränderliche Element der vom Zeitpunkt abhängigen Entfaltung der materiellen Wirkkraft. Bashō behandelt in dieser Hinsicht das Haikai nicht anders als jedes andere Element der Welt in deren Gesamtheit: Nur, wo das Unwandelbare und das Dahinströmende zusammenkommen, entstehe das Wahre (makoto). In den diversen sich auf den Meister berufenden Bashō-Schulen wurde fueki ryūkō zu einem zentralen Terminus, und zwar weitgehend gleich interpretiert.

Eine gegenüber dem Kyorai shō etwas variierte fueki - ryūkō-Theorie findet sich nämlich beispielsweise im Shi Shin mondō 柿晋問答 ([Fragen und Antworten zwischen Shi und Shin]), einer nachgedruckten Sammlung von Aufzeichnungen der Gespräche zwischen den Bashō-Schülern Mukai Kyorai (Rakushi sha 落柿舎) und Takarai Kikaku (Shin shi 晋子). ${ }^{196}$ Kajitsu 花実 deckt sich hier mit der Dichotomie „Unwandelbares - Dahinströmendes“, also der in einem Gedicht geschaffenen Verbindung innerer geistiger Konstanten und deren Kom-

193 NKBT 66: 362-363.

194 Originaltext: MATSUO-TANAKA 2005 [1690]: 778-780. Tanaka hält den Brief allerdings nicht für authentisch.

195 S. S. 8.

196 Enthalten sind auch Teile der Gespräche zwischen Kyorai und dessen jüngerem Bruder Rochō 魯町 (= Mukai Gensei 向井元成, 1656-1727) über die von Kyorai tradierte Bashō-Theorie vom „Unveränderlichen und Dahinströmenden“ (fueki ryūkō), Teile aus Gesprächen zwischen Takarai Kikaku und seinem Schüler Sekisō 尺草 über Kikakus „Theorie vom Neuen und Alten“ (shinko ron 新古論) und schließlich auch Bewertungen von Gedichten, die im gleichen Wortlaut auch im ebenfalls 1775 gedruckten Kyorai shō enthalten sind. Kanda Toyoho 神田豊穂, der Kommentator des modernen Nachdrucks in Bd. 4 der Serie Nihon haisho taikei 日本俳書大 系 (1926), hält es für möglich, dass aus dem gleichzeitig gedruckten Kajitsu shū 花実集 Teile in das Kyorai shō übernommen wurden (MUKAI-TAKARAI-KANDA 1926 [1775]: kaidai 6-7). Iмото 1961 zweifelt dagegen für den erst 50 bis 70 Jahre nach Kyorais Tod erschienenen Text die direkte Autorschaft Kyorais an. 
bination mit variablen Formen des äußeren materiellen Ausdrucks dieser Konstanten, wie aus der folgenden Passage des Vorworts in eigener Übersetzung hervorgeht.

Kyorai sprach: „In der Schule Bashōs gibt es Verse über Dinge, welche sich in tausend Jahren nicht verändern, und Verse [über Dinge], welche zu einem Zeitpunkt dahinströmen, und [der Meister] lehrte uns, indem er [das Dichten] in diese beiden unterteilte, aber deren Ursprung ist ein und derselbe. Erkennt man das Unveränderliche nicht, so kann die Grundlage nicht Bestand haben, begreift man nicht das Dahinfließen, so ist der Stil nicht neu. Man spricht vom über tausend Jahre Unveränderlichen, wenn ein Vers über alte [Dinge] zum folgenden passt. Dahinströmen meint die Änderungen zu einer und zu anderen Zeiten, der Stil von gestern ist heute nicht mehr genehm, der heutige Stil kann morgen nicht mehr verwendet werden, weswegen man vom Dahinströmen zu einer Zeit spricht. Das meint, etwas Vorübergehendes zu tun.“197

Wie wirksam die teils mündlich, teils in handschriftlichen Aufzeichnungen kursierenden Thesen des Meisters Bashō waren, zeigen die 1702 (acht Jahre nach seinem Tod) entstandenen drei Notizhefte Shirozōshi ([Weißes Notizheft]), Akazōshi ([Rotes Notizheft]) und Wasuremizu ([Wasser des Vergessens]) des Haikai-Dichters Hattori Dohō 服部土芳 (1657-1730), ebenfalls ein seinem Meister Matsuo Bashō treu ergebener Schüler, dessen Klause Minomushian in der Provinz Iga ein bedeutendes lokales Zentrum der Bashō-Schule war. ${ }^{198}$ Dohō gebührt das Verdienst, die literaturtheoretischen Überlegungen Bashōs in den erwähnten Notizheften in unübertroffener systematischer Klarheit zusammengetragen zu haben. Dabei waren die Notizen nur als ständig verfügbares Lehrmaterial für seine eigenen Schüler gedacht und nicht für eine Verbreitung in gedruckter Form vorgesehen. Die drei Hefte sind trotz inhaltlicher Überschneidungen zwischen den Heften Akazōshi und Wasuremizu relativ unabhängig und kursierten über 70 Jahre getrennt vonein-

197 Kyorai iwaku, shōmon ni senzai fueki no ku, ichiji ryūkō no ku ari, kore wo futatsu ni wakete oshie tamaeru, sono moto wa hitotsu nari. Fueki wo shirazareba, moto tachigataku, ryūkō shirazareba, fū arata narazu. Fueki wa ko ni yoroshiku ato ni kanau ku naru yue, senzai fueki to iu. Ryūkō wa ichiji ichiji no hen ni shite, kinō no fū kyō yoroshikarazu, kyō no fū asu ni mochiigataki yue, ichiji ryūkō to wa ii haberu nari. 去来曰、蕉門に千載不易の句、一時流行の句有、是を 二ッに分けて教へ給へる、其元はひとつ也。不易を知らざれば、基たちがたく、流行しらざ れば風新ならず。不易は古によろしく後にかなふ句なる故、千載不易といふ。流行は一 時々々の変にして、きのふの風けふよろしからず、今日の風明日に用ひがたき故、一時流行 とはいひ侍る也。 (NKBT 66: 359). Der moderne Nachdruck in Shōmon haiwa bunshū (1926) weicht in Wortlaut und Schreibung von der hier zitierten Version ab. (MUKAI-TAKARAI-KANDA 1926 [1775]: 268).

198 Als 1691 die Bashō-Schüler Kyorai und Nozawa Bonchō 野沢凡兆 (1640-1714) das Sarumino 猿蓑 (The Monkey‘s Straw Raincoat), eine Sammlung von hokku des Meisters Bashō und seiner Schüler, zusammenstellten, lieferte die Schule des Hattori Dohō mit 29 Beiträgen den größten Anteil. 
ander unter Hattoris Schülern in teilweise voneinander abweichenden und teilweise fehlerhaften Abschriften, bevor sie unter dem Titel Sanzōshi ([Drei Hefte]) zusammengefasst wurden. Auch das Sanzōshi räumt Bashōs Theorie von der Verbindung unveränderlicher und wandelbarer Gegenstände in der Dichtung eine Sonderstellung ein. Die nachstehend zitierte Passage verdichtet die alle drei Hefte durchziehenden Gedanken, die es gegenüber den zuvor zitierten Varianten wiederum leicht variiert.

Was die vom Meister [gelehrte] Eleganz betrifft, so besteht sie im Unveränderlichen bei den Zehntausend Zeitaltern [= Ewigkeit] und dem Wandelbaren in einer Zeit. Diese beiden [Elemente] bilden Extreme, doch ihr Ursprung ist das Eine. Was ich das Eine nenne, das ist die Wahrhaftigkeit der Eleganz [füga no makoto]. Wer vom Unveränderlichen nichts weiß, der kennt sich auch im Wirklichen [jitsu] nicht aus. Was ich das Unveränderliche nenne, ist das vom Neuen und Alten Unabhängige und hat nichts mit Wandlungen noch Strömungen zu tun, sondern ist eine fest in der Wahrhaftigkeit stehende Form. Schaut man sich die Gedichte der Dichter verschiedener Zeitalter an, so gibt es in jedem Zeitalter Veränderungen. Geht man aber nicht vom Neuen hinüber zum Alten und schaut [nur] auf die jetzigen, so sind sie nicht anders als diejenigen, die man früher gesehen hat, und es sind darunter viele Gedichte, welche traurig stimmen. Daran kann man zunächst das Unveränderliche erkennen. Was nun die sich tausendmal verändernden und zehntausendmal wandelnden Dinge betrifft, so liegt ihnen ein Prinzip der Natur zugrunde. Gehen sie im Wandel nicht [in anderes] über, so ändert sich nicht ihre Erscheinung. Sagt man, dies hier wandele sich nicht, so ist das nur eine vorübergehend modische Redeweise, welche den [richtigen] Zeitpunkt getroffen hat, weil sie nicht nach dem Wahrhaftigen gestrebt hat. Man kann nicht sagen, dass jemand die Wandlung des Wahrhaftigen begriffen hat, wenn er sein Herz nicht belastete und nicht [danach] strebte. Das ist nur ein fortgesetztes Nachahmen anderer. Wer [nach dem Wahrhaftigen] strebt, der kann seinen Fuß nicht auf das Gebiet [der anderen] setzen, es ist vielmehr sein Prinzip, einen Schritt weiter in die Natur voranzugehen. Wenn auch am Ende des Weges alles sich tausendmal ändert und zehntausendmal wandelt: Alle Veränderungen der Wahrhaftigkeit sind in den Haikai des Meisters [enthalten]. ${ }^{199}$

Was hat nun die Dichotomie „Unveränderliches - Wandelbares“ mit dem Thema der vorliegenden Abhandlung, mit „Leere“ und „Fülle“, mit Fiktionalität und

199 Shi no füga ni bandai fueki 万代不易 ari. Ichiji no henka ari. Kono futatsu ni kiwamari, sono moto hitotsu nari. Sono hitotsu to iu wa füga no makoto nari. Fueki wo shirazareba makoto 実 ni shireru ni arazu. Fueki to iu wa, shinko ni yorazu, henka ryūkō ni mo kakawarazu, makoto ni yoku tachitaru sugata nari. Daidai no kajin no uta wo miru ni, daidai sono henka ari. Mata shinko ni mo watarazu, ima miru tokoro mukashi mishi ni kawarazu, aware naru uta ōshi. Kore mazu fueki to kokoroe beshi. Mata senben banka 千変万化 suru mono wa jinen no kotowari 自然 の理 nari. Henka ni utsurazareba fū aratamarazu, kore ni oshiutsurazu to iu wa, ittan no ryūkō ni kuchiguse toki wo etaru bakari nite, sono makoto wo semezaru yue nari. Semezu kokoro wo korasazaru mono, makoto no henka wo shiru to iu koto nashi. Tada hito ni ayakarite yuku nomi nari. Semuru mono wa sono chi ashi wo suegataku, ippo jinen ni susumu kotowari nari. Yuku sue iu senben banka suru tomo, makoto no henka wa mina shi no haikai nari. (NKBT 66: 397). 
Wirklichkeit zu tun? Es zeigt sich beim Studium insbesondere der Haikai-Theorien seit Bashō, dass das Unveränderliche (fueki) sich inhaltlich mit dem Allgemeinen, dem nicht Individualisierten oder Konkretisierten, dem Beständigen (tsune 常), dem nicht Sichtbaren deckt, ryūkō demgegenüber mit dem Konkreten, Individualisierten, Flüchtigen und Sichtbaren. Beide Elemente gehören zur Wirklichkeit, das Veränderliche kann in der Dichtung eine Verkörperung des Unveränderlichen sein, muss es aber nicht. Für Bashō ist vielmehr entscheidend, dass in der Balance der beiden Sphären das entsteht, was er makoto (etwa „Wahrhaftigkeit“ oder „Aufrichtigkeit“) nennt. Ein weiterer prominenter Apologet dieses Ideals und seiner technischen Umsetzung in der Haikai-Dichtung ist Bashōs Zeitgenosse Uejima Onitsura 上島鬼貫 (1661-1738), dessen berühmtes Diktum, dass abseits von makoto kein Haikai sei, ${ }^{200}$ durch die folgende Passage aus seinen „Selbstgesprächen“ (Hitorigoto 独こと, 1718) spezifiziert wird.

Diejenigen, welche sich diese [Dicht]kunst angeeignet haben und sprechen [= dichten], ohne Kraft in das Leere oder die Fülle zu geben, sprechen Gedicht für Gedicht aus, dass das Ungelogene die Wahrheit an sich sei. Der Grund hierfür ist sicherlich, dass es beim Sinn des Beständigen nichts Gelogenes gibt und man auch seine Gedanken tief in das Angerührtsein von den Dingen der Welt versenkt. ${ }^{201}$

Diese Passage ist ein weiterer Beleg für die bei verschiedener Formulierung große Deckung literaturtheoretischer Begriffe und damit auch für ihre grundsätzliche Bedeutsamkeit. Das „Beständige“ (tsune) in Onitsuras Text meint dasselbe wie das „Unveränderliche“ (fueki) bei Bashō, ${ }^{202}$ „Leere“ (kyo) steht im Extremfall (wenn Kraft in sie gegeben wird) für „Gelogenes“ (itsuwari), „Fülle“ (jitsu) für „Wahrhaftigkeit“, aber nur wenn sie nicht gewaltsam (mit Kraft) in den Mittelpunkt gestellt, sondern mit „Leere“ verbunden wird. Im Ganzen propagiert auch Onitsuras Text die Materialisierung immaterieller Gegenstände durch ungezwungene und natürliche Sprache, wie dies schon das kana-Vorwort des Kokinshū tat. ${ }^{203}$

200 Makoto no hoka ni haikai nashi まことの他に俳諧なし. Original: UEJIMA-OKADA 1968 [1718]: 194; Übersetzungen: „Apart from makoto, there is no haikai“ (CROWLEY 1995: 1); „Außerhalb der Wahrhaftigkeit gibt es kein haikai““ (NAUMANN 1963: 55).

201 Kono michi wo shūshi etaran hito no, kyo jitsu no futatsu ni chikara wo irezu shite iidasu tokoro, kugoto ni itsuwari naki wo koso onozukara no makoto to wa iihaberikere. Kore nan tsune no koro ni itsuwari naku, yo no aware wo mo fukaku omoiiretaru yue naru beshi. 此の道を修し 得たらん人の、虚実のふたつに力を入れずしていひ出す所、句毎にいつはりなきをこそをの づからのまこととはいひ侍るけれ。是なん常の心に偽りなく、よのあはれをも深くおもひ入 れたる故なるべし。(FUкUмOTо 1981 [1718]: 35).

202 FUкUмото 1981 [1718]: 36.

203 Siehe Abschn. 3.4.2.2. 


\subsubsection{Das Unsichtbare ist statisch, das Sichtbare dynamisch: Das Kien shiwa (1771) des Minagawa Kien}

Einen weiteren Aspekt im Zusammenhang mit dem „Unveränderlichen“ und dem „Dahinfließenden“ bringt der konfuzianische Gelehrte Minagawa Kien 皆川淇園 (1735-1807) ein. Kien verfasste neben umfangreichen Kommentaren zu chinesischen Klassikern, so etwa einer Studie über den Zusammenhang von Zeichenetymologie, Phonetik und Phraseologie im Yijing, auch eigene Dichtungen und literaturtheoretische Schriften. Unter letzteren herausragend ist das Kien shiwa 淇園詩話 ([Kiens Gespräche über die Poesie], 1771). ${ }^{204}$ Kien legt dort dar, dass Poesie (shi 詩) aus den drei Elementen äußere Form (teisai 体裁), Tonlage (kakuchō 格調, im Sinne von Stil) und Wesen (seishin 精神) bestehe, wobei letzteres als ein die Form und die Tonlage (den Stil) zusammenfassendes Moment die tragende Rolle spiele. Das Wesen der Poesie müsse man durch Kontemplation (meisō 顛想) erfassen, die Minagawa als stille Begegnung mit einem Betrachtungsgegenstand (mokkai 默会) und eintauchendes Ergründen (senri 潜理) bezeichnet. Alle Dinge zwischen Himmel und Erde träten in Abhängigkeit von Empfindungen (kan 感) in Erscheinung und wandelten sich in Abhängigkeit von Gedanken (nen 念). Was nun Empfindungen und Gedanken beherrsche, sei der Geist (seishin 精神). Nach dieser Entwicklung der Begriffe seishin, meisō sowie kan und nen erläutert Minagawa seine Unterscheidung zwischen der Reaktion auf die Außenwelt und der Kontemplation. Dabei nimmt er den für die literarische Produktion wichtigen Gemütszustand des Künstlers wie folgt in den Blick.

Wohl während der Kontemplation und Verzückung nehmen Himmel und Erde ihre Positionen ein und werden mit allen Dingen ausgerüstet. Sie treten dem Gefühle folgend in Erscheinung, sie wandeln sich dem Gedanken folgend. Was Gefühl und Empfinden beherrscht, wird Geist genannt. Er beobachtet still die Situation und den Zustand eines Gegenstandes und hat dabei wohl etwas anderes an sich als der Prozess des Reagierens auf das Äußere des Alltagslebens. Die Reaktion auf das Äußere kehrt sich bald um, bald verändert sie sich; Bewegung und Innehalten sind nicht von Bestand, und doch kommt es nicht vor, dass sie auch nur vorübergehend nicht existierten. Bei etwas wie dem Geist im Zustande der Kontemplation verhält es sich nicht so. Bei der Äußerung des Empfindens folgt der Mensch auf jeden Fall seinen Neigungen, konzentriert seine geistigen Fähigkeiten, bringt Gedanke für Gedanke in eine kontinuierliche Reihenfolge und hält sie fest, um schließlich sein Herz zu besänftigen. Erst wenn er all dies getan hat, mag es von längerer Dauer sein. ${ }^{205}$

204 Einen modernen Nachdruck bietet MinAGAWA-IKEDA 1972 [1771] (NSS 5: 177-226).

205 Kedashi myōsō kyōkotsu no aida, tenchi i shi, banbutsu sonawaru. Kanji ni shitagaite gen shi, nen ni shitagaite henzu. Kono kan nen wo tsukasadoru mono, sunawachi iwayuru seishin nari. Sono mono no jōjō wo seisatsu teikan su domo, kedashi heisei gai ni ōzuru no sayō to, onajikarazaru ari. Gai ni ōzuru no sayō wa, tachimachi tenji tachimachi kawaru. Dō shi tsune naku shite shikōshite toki 
Das hier mit gai 外 („Äußeres“) nur zur Hälfte explizit genannte Begriffspaar „Inneres - Äußeres“ ist eine weitere terminologische Variante der bereits genannten Dichotomien. Noch interessanter als diese Erweiterung des Wortschatzes ist aber die rationale Selbstkontrolle, welche Minagawa dem Menschen im Allgemeinen und dem Dichter im Besonderen bei der Äußerung von Gefühlen auferlegt: Ist der Impuls des Dichtens noch das Gefühl, wird das Dichten selbst zu einem intellektuellen Akt, dessen Ziel die methodisch wohlüberlegte Einbringung des Zeitlosen in den Fluss der Zeit ist. Am interessantesten im Zusammenhang der vorliegenden Abhandlung ist freilich der Begriff des „in Erscheinung tretenden Gefühls“ (kangen 感現), der die Sphären des Unsichtbaren und Statischen auf der einen Seite und des Sichtbaren und Dynamischen auf der anderen Seite unterscheidet und gleichzeitig zusammenbringt. Das ist im Ergebnis genau dasselbe wie die weiter oben besprochene Theorie Bashōs vom „Unwandelbaren“ und „Dahinströmenden“.

Der Literaturkritiker Ishibashi Ningetsu bringt in seiner Abhandlung „Über die Idee und das Wirkliche“ (Sō jitsu ron 想実論, 1890) ${ }^{206}$ Kiens Vorstellungen mit Paraphrasen des $\S 19$ aus Deutsche Poetik des Literaturhistorikers und Literaturkritikers Werner Hahn (Berlin 1879) zusammen - ein neuerlicher Beweis der Grundsätzlichkeit und der Aktualisierbarkeit des über lokale und zeitliche Grenzen hinweg wichtigen Themas der vorliegenden Abhandlung.

to shite sonsezaru koto nashi. Myōsō chū no seishin no gotoki wa sunawachi shikarazu. Sono kan gen no toki ni atarite, sono hito kanarazu subekaraku shi wo tsugi $i$ wo atsumete, nennen aitsugi, motte kore wo shüji shi, motte kore kangan shite, shikōshite nochi ni hajimete chōson suru koto wo ebeshi. 蓋冥想怳惚之間、天地位焉、万物備焉、随感而現、随念而変、主此感念者、即所謂精 神也、静察訂観其物情状、蓋与平生応外之作用、有不同、応外之作用者、旋転旋易、動止無 常、而無時而不存、如冥想中之精神、乃不然、方其感現之時、其人必須継志緝意、念念相継 以執持之、以観玩之、而後始得長存、(MINAGAWA-IKEDA 1972 [1771]: 181-182).

206 Mit dem Übersetzungswort „Idee“ für das japanische sō 想 übernehme ich die begriffliche Zuordnung, die Mori Ōgai 森鴎外 (1862-1922) in seinem Beitrag ,Bungaku to shizen“ wo yomu

「文学卜自然」习読ム(Bei der Lektüre von ,Literatur und Natur‘, Kokumin no tomo 50, Mai 1889) verwendet. Mori legt in diesem Beitrag dar, dass die Phänomene der Natur in der Wirkung einer Ursache entstünden und zugleich als Ursache bewirkten, dass andere Phänomene entstehen. Wenn ein Mensch diese unendliche Ausdehnung der Phänomene in Teile zerlege und die Trennlinie zwischen Ursache und Wirkung überschreite, so könne man die Entstehung einer Idee beobachten. Die Idee sei der Sinn des Unendlichen, den man an einem endlichen Gegenstand erkennt (KBHT 1:70-71). Mori bedient sich dabei einer zu seiner Zeit verbreiteten Praxis, indem er einen ausländischen Begriff in der für fremdsprachliche Begriffe verwendeten Silbenschrift katakana notiert (hier idē イデー für das deutsche „Idee“) und diesen fremdsprachlichen Begriff mit einem bekannten japanischen Begriff in sinojapanischer Schrift (kanji) (hier sō 想) parallel setzt (Vgl. WoLDERING 2015a). Eine komplette, kommentierte Übersetzung von Ishibashis Abhandlung bietet WOLDERING 2017/2018. 


\subsubsection{Die Mustersammlung und die Entwicklungsmöglichkeiten der japanischen Literaturtheorie}

In den vorausgehenden Abschnitten wurden Beziehungsmuster zwischen „Leere“ und „Fülle“ (Fiktion und Wirklichkeit) in literarischen Texten, die in einschlägigen theoretischen Texten tatsächlich auffindbar waren, erarbeitet und systematisiert. Dass in diesem (wie gesagt nicht funktional synchron intendierten) System weitere prinzipiell mögliche Beziehungsmuster fehlen könnten, soll als Arbeitshypothese den Ausgangspunkt der zweiten Hälfte der Abhandlung bilden. Es wird im Folgenden also auf die Frage ankommen, ob der aus der Geschichte der japanischen Literaturtheorie der Jahre 914-1850 extrapolierte Vorrat an Mustern der Beziehung zwischen Fiktion und Wirklichkeit in den sich daran anschließenden Jahren 18501890 ausgeschöpft und womöglich gar verändert oder erweitert wurde. 